يهدف هذا البحث إلى دراسة موضوع "الوصية للوارث: دراسة فقهية تحليلية". وقد تناول البحث بيان تعريف الوصية، وتوضيح معنى الوارث في الفقه

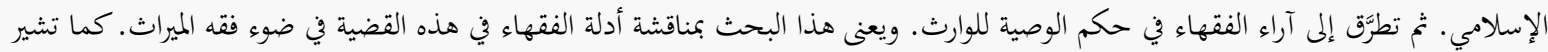

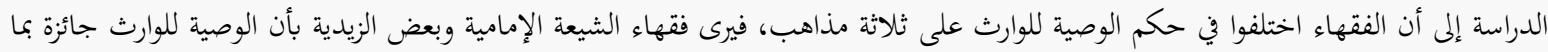

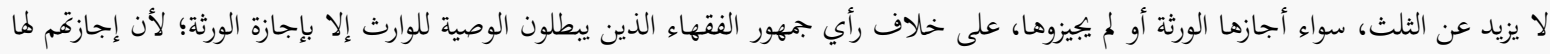

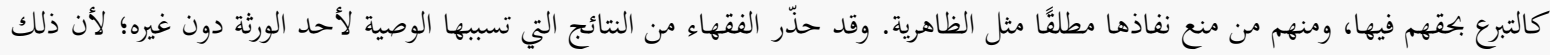

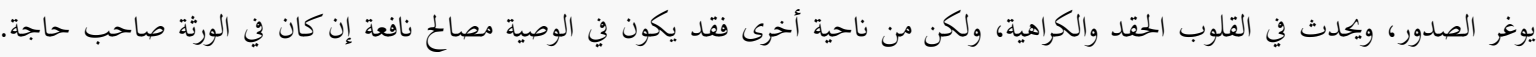

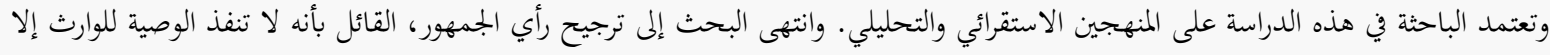

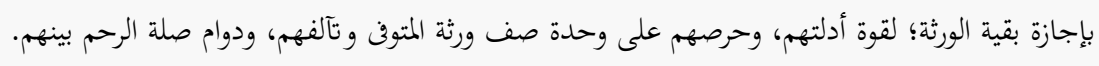
الكلمات المفتاحية: الوصية، الوارث، الدراسة الفقهية، الإجازة إلهارة
\end{abstract}

\title{
The Will for Heirs: A Juristic Analytical Study
}

\section{Abstract}

This research aims to study the topic of "The Will for Heirs: A Juristic Analytical Study." It deals with the definitions of will or testament and heirs from the perspective of Islamic jurisprudence. It discusses the views of jurists regarding the ruling of will for heirs by discussing proofs of jurists on this issue in the light of Islamic law of inheritance. This research discovers that the Muslim jurists differed on the law of will for heirs according to three schools of thought: according to Sh'̈'ah Imämiyyah and some supporters of Zaydiyyah, the will for heirs is permissible in one-third whether approved by the other heirs or not. This view differs from the majority of jurists who invalidate the will for heirs except by the permission of the other heirs because their permission is like a forfeiture of their right. Others, such as Zāhiriyyah, opposed the implementation of will for heirs. They argued that the will, will cause dissatisfaction in other heirs or inheritors. On the other hand, the will for heirs is useful and beneficial for some of the needy heirs. The researchers rely on the inductive and analytical methods. One of the important findings of this research is that, relying on the majority opinion of jurists, the law of will for heirs is valid only with the permission of the rest of the heirs after the death of the testator; this is the best opinion based on the strength of the evidence and their keenness on the unity of the heirs of the deceased.

Keywords: Will, Heir, Juristic Study, Permission

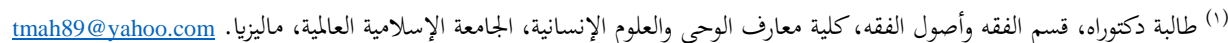

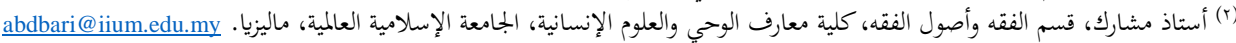

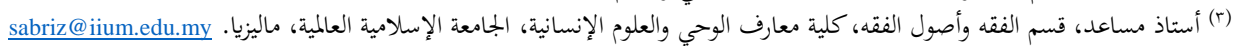

$$
\text { المطلب الثاني: الوصية للوارث صحيحة بإجازة الورثة }
$$$$
\text { لمطلب الثالث: الوصية للوارث صحيحة سواء أجازها الورثة أم لم }
$$

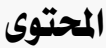

90

$$
\begin{aligned}
& \text { المقدمة المبتوي } \\
& \text { المبحث الأول: تعريف الوصية } \\
& \text { المطلب الأول: تعريف الوصية لغةً } \\
& \text { المطلب الثاني: تعريف الوصية اصطلاحًا } \\
& \text { المبحث الثاني: تعريف الوارث } \\
& \text { المطلب الأول: تعريف الوارث لغةً } \\
& \text { المطلب الثاني: تعريف الوارث اصطلاحًا } \\
& \text { المطلب الأول: الوصية للوارث باطلة مطلقا }
\end{aligned}
$$$$
\text { المبحث الثالث: آراء الفقهاء في حكم الوصية للوارث }
$$ 
إضافة إلى ذلك، فإن معظم الدراسات المعاصرة تتناول

موضوع الوصية للوارث من حيث بيان أحكامها بصورة بجملة

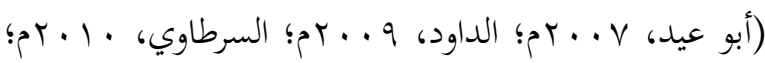
محمد جفري، 0 ( • rم)، ولم تقم بتحليلها بالتفصيل؛ وعليه فسيجتهد الباحثون في تحليل آراء الفقهاء في حكم الوصية

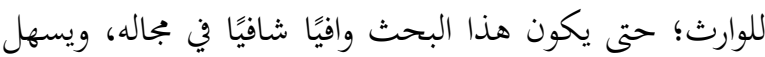
على الناس الرجوع إليه، والإفادة منه. إن الوصية شرعت أصلاً لفعل خير، ولكن الوصية للوارث قد تثير البغضاء والأحقاد بين الأفراد، خاصةً إذا استغلها

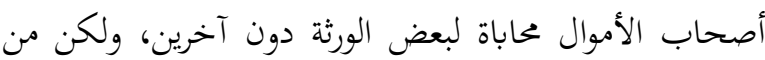

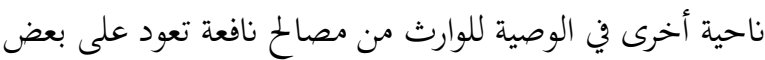
الورثة الضعفاء والصغار.

ولما كان الورثة في أغلب الأحيان متفاوتين في الفقر

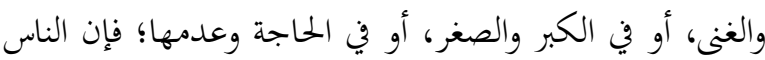
يميلون إلى تمييز من يكون محتاجًا إلى مالهم، ولا يجدون في أحكام الوصية المعمول بها الآن ما يحقق لمم أغراضهم؛ لأن توقف نظام

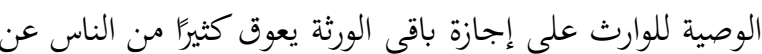
برِّ من يكون أشد حاجة إلى برِهم من ورثتهم. ولذذه المعاني؛ ثارت تساؤلات بين المسلمين حول مدى مشروعية الوصية للوارث، وهل من العدل أن تنفذ الوصية للوارث

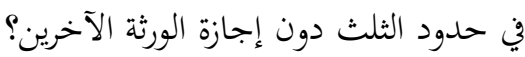

\section{المبحث الأول : تعريف الوصية}

المطلب الأول: تعريف الوصية لغةً الوصية: مصدر من "وصَّى"، وتعني الإيصال، وهي مأخوذة من "وصيت الشيء" إذا وصلته، ويقال: أرض واصية، أي متصلة النبات. وتطلق على "الإيصاء" بمعنى العهد إلى الغير في القيام

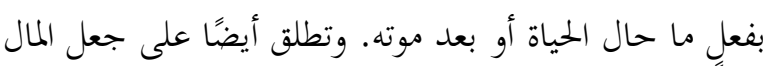

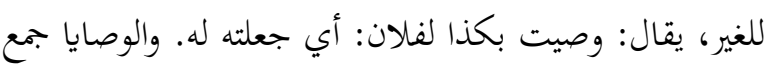
وصية تعم الوصية بالمال والإيصاء أو الوصايا (ابن منظور،

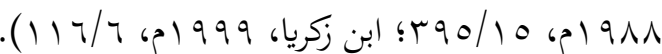

\section{المقدمة}

الحمد لله رب العالمين، والصلاة والسلام على رسول الله وعلى آله وأصحابه ومن تبعهم بإحسان إلى يوم الدين، أما بعد. أما بعد، فقد وضع الإسلام الأسس الواضحة؛ لتحقيق

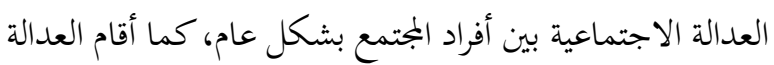
بين أفراد الأسرة نواة المجتمع الذين تربط بينهم روابط دموية.

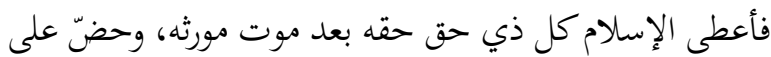
الوصية للأقارب، وعلى التصدق على الفقراء والمساكين، وعلى الإنفاق في سبيل الله؛ حتى لا يحدث خلل من شأنه التأثير على

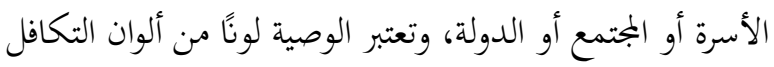

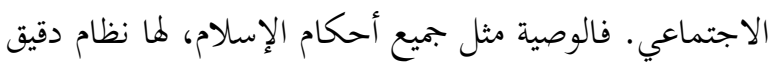
قائم على الحق، والعدل، والرحمة، ونشر الخير؛ لتحقيق المصلحتين

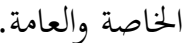

الوصية هي التصرف في التركة المضاف إلى ما بعد الموت. وهي في حد ذاهما جائزة شرعًا في حدود ثلث ما يملك الإنسان، وقد منع رسول الله رسول الله

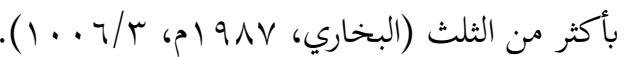
ويعد موضوع الوصية للوارث من المواضيع التي أثارت جدلاً فقهيًا كبيرًا، فقد اختلف أهل العلم في هذه المسألة، فالجمهور ذهبوا إلى القول ببطلاها إلا بإجازة الورثة المؤهلين بعد وفاة الموصي، ومن العلماء من ذهب إلى القول بمنعها مطلقًا

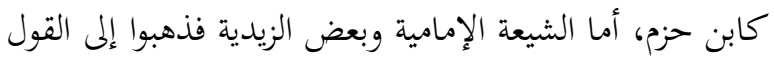
بمشروعيتها في حدود الثلث من غير توقف على إجازة الورثة؛ ولكل مذهب أدلته. وبناءً عليه، فإن هذا البحث سيتناول قضية في غاية الأهمية، وهي الوصية للوارث، ومدى مشروعيتها في الإسلام، وتحليلها في ضوء فقه الميراث؛ وذلك مساهمةً في خدمة لخدة

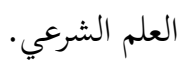
ومن خلال التتبع والبحث، يتبيّن أن موضوع الوصية قد تطرَّق له الفقهاء، ولا يكاد يخلو كتاب من كتب الفقه من موضوع الوصية، ولكن موضوع الوصية للوارث يناقش عند مناقشة شروط الموصى له. 
وترى الباحثة أن التعريف الراجح للوصية أها ""تمليك

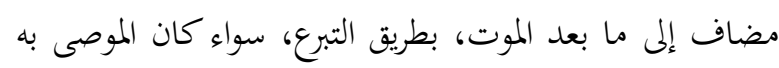

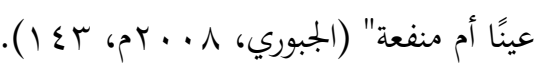

\section{المبحث الثاني : تعريف الوارث}

$$
\text { المطلب الأول: تعريف الوارث لغةً }
$$

الوارث: أصلها ثلاثي من "ورث"، يقال: ورث أباه، يرِثه بكسر

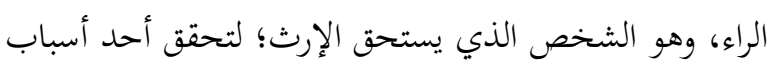

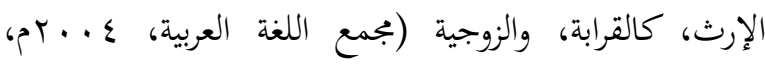

$$
\text { .(1. r } \varepsilon
$$

وسمي من يستحق تركة الميت أو بعضها وارثًا؛ لبقائه،

وانتقال مال الميت إليه، ومن ذلك دعاء النبي ئس بسمعي، وبصري، واجعلهما الوارث مني)) (الترمذي،

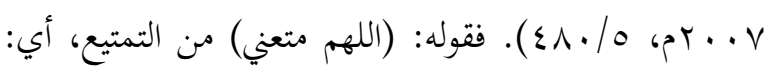

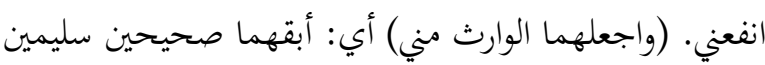

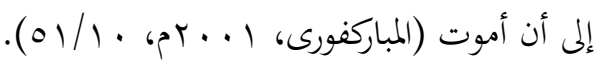

المطلب الثاني: تعريف الوارث اصطلاحًا الوارث هو من يستحق جزءًا من تركة المورث فرضًا بنص من

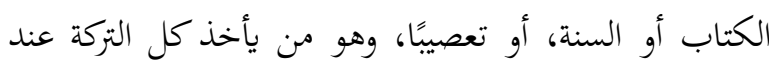
الانفراد، أو الباقي بعد أصحاب الفروض، أو فرضًا وتعصيبًا

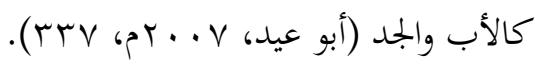

وبعبارة أخرى، الوارث هو الإنسان الذي يرتبط بالميت

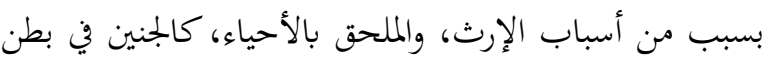

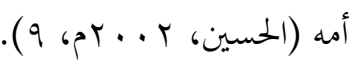

\section{المبحث الثالث : آراء الققهاء في حكم الوصية للوارث}

اختلف الفقهاء في حكم الوصية للوارث على عدة مذاهب، ولكل مذهب منها أدلته، وستذكر الباحثة المذاهب ابتداء، ثم تعرض مناقشة أدلة كل فريق.
وسميت وصية؛ لأن الموصي يصل بها ما كان في حياته بعد مماته، أو لأن الموصي يصل خير دنياه بخير أخرته (الشوكاني،

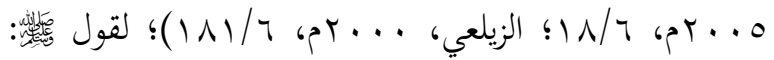
((إذا مات ابن أدم انقطع عمله إلا من ثلاثة أشياء: صدقة

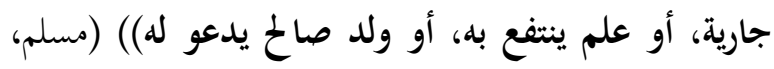

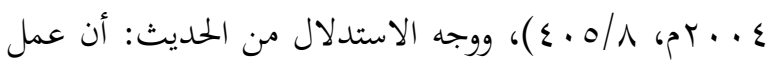
الميت ينقطع بموته، وينقطع بحدد الثواب له إلا في هذه الأشياء الثلاثة؛ لكونه كان سببها، فإن الولد من كسبه، وكذلك العلم الذي خلفه من تعليم أو تصنيف، وكذلك الصدقة الجارية، وهي

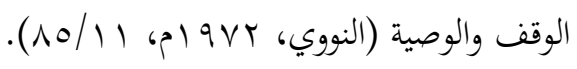

المطلب الثاني: تعريف الوصية اصطلاحًا للوصية في اصطلاح الفقهاء تعريفات مختلفة حسب مذاهبهم، لكنه اختلاف شكلي لا يمسّ الجوهر والمضمون، وإليه بيان هذه التعريفات: فقد عرّفها صاحب "البحر الرائق" من الحنفية بأغها:

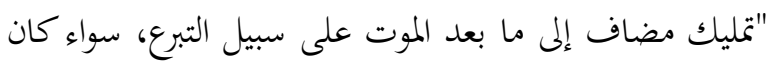

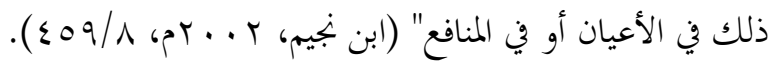

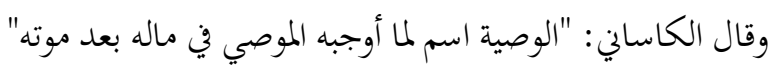

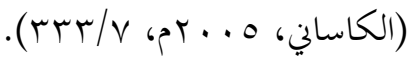

وقال الحطاب في "مواهب الجليل" "الوصايا حقيقتها تصرف المالك في جزء من حقوقه، موقوف على موته، على وجه

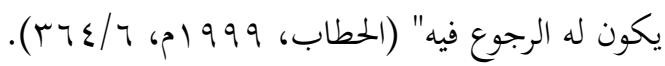
وعند الشافعية قال الخطيب الشربيني: "هي تبرع بحق

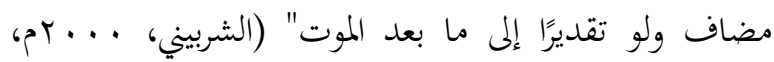
.$(r q / r$

وعند الحنابلة قال البهوتي في كشاف القناع: "الوصية

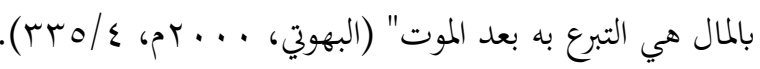
ويلاحظ أن معظم هذه التعريفات اقتصرت على الوصية

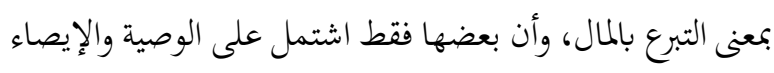

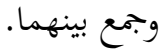


ا ـ ما رواه أبو أمامة عن رسول الله

المطلب الأول: الوصية للوارث باطلة مطلقا

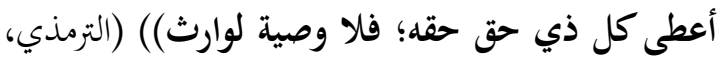

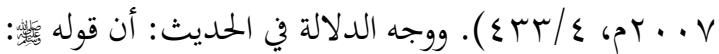

(لا وصية لوارث) صريح في نفي الوصية للوارث، والنفي إنما

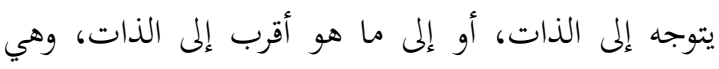

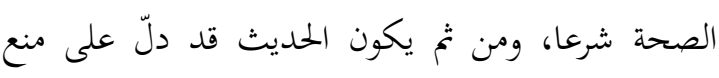
الوصية للوارث. وإذا أجاز باقي الورثة فإن ذلك يكون هبة لهن

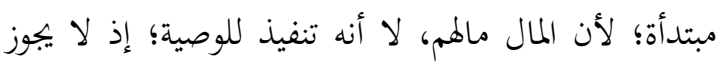

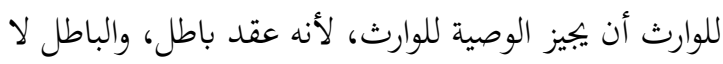

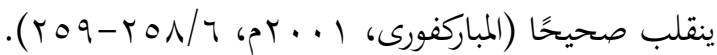
r. في الوصية للوارث إلحاق الضرر ببقية الورثة، وقد هیى القرآن

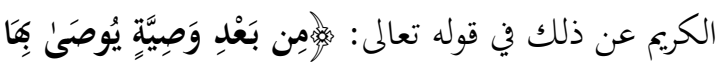

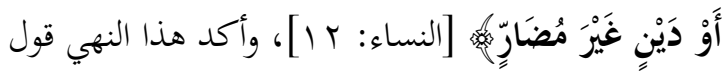

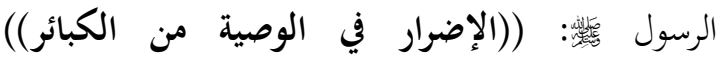

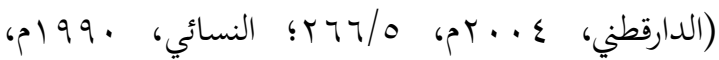

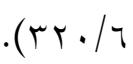

r. ويُوَيَُّد ما ذهب إليه هذا الفريق بأن الله تعالى قد أعطى كل ذي حق حقه في الميراث، وأن عدالة الإسلام توجب الالتزام بما جاء في نصوص الشريعة الإسلامية؛ فلا يجوز أن يتميز وارث عن وارث، فإن أخذ أحد الورثة نصيبه في الميراث،

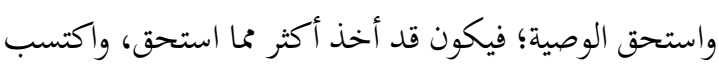

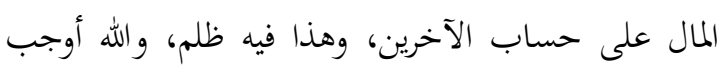

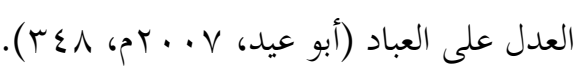

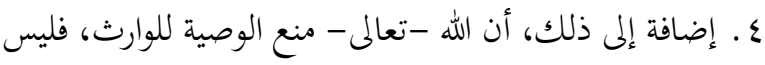

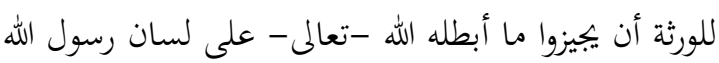


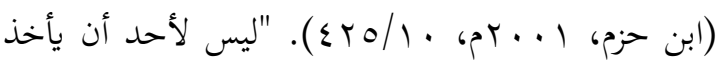

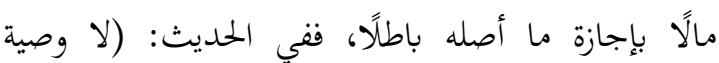

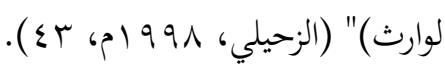

قال بعض الفقهاء بأنه لا تجوز الوصية للوارث مطلقًا، سواء

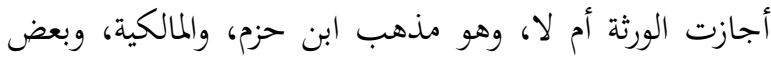

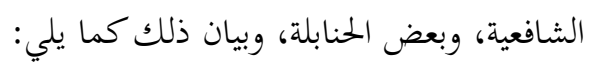
قال الظاهرية لا تحل الوصية لوارث أصلا، فإن أوصى لونى لغير وارث، وصار وارثًا عند موت الموصي، بطلت الوصية له. فإن أوصى لوارث، ثم صار غير وارث لم تجز له الوصية؛ لأفها إذا

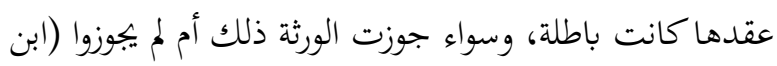

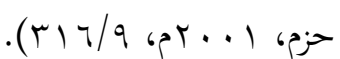
وقال المالكية: تبطل الوصية للوارث، بأن يوصي بما

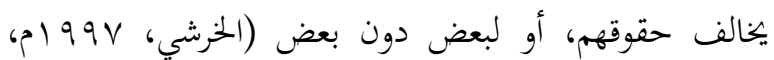
$.(1 \mathrm{~V}) / \mathrm{\Lambda}$

وقال الشافعية: واختلف قول الشافعي في الوصية

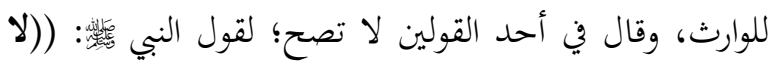

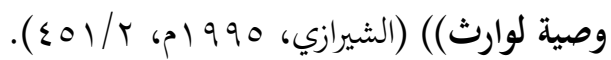
وقال ابن قدامة في المغني: "قال بعض أصحابنا: الوصية باطلة وإن أجازها سائر الورثة، إلا أن يعطوه عطية مبتدأةً؛ أخذًا

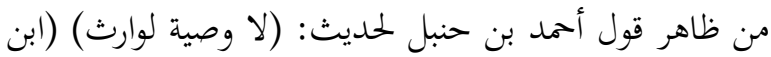

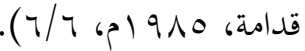
إذًا، لا تجوز الوصية للوارث أصلاً سواء أجازها الورثة أم لم يجيزوها، وتقع باطلة غير منعقدة، إلا أنه إذا أجازها الورثة فابتداءُ عطيةٍ من عند أنفسهم من مالهم الذي آل إليهم من مورثهم، وتفتقر حينثٍٍ إلى شروط الهبة من اللفظ والقبول والقبض، لا أفها تنفيذّ لوصية الموصي. فإن أوصى لغير وارث وصار وارثًا عند موت الموصي،

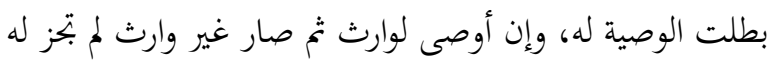

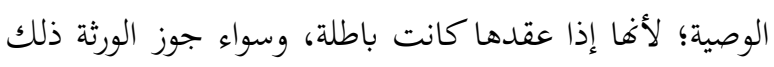

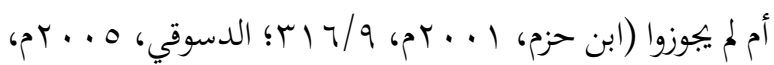

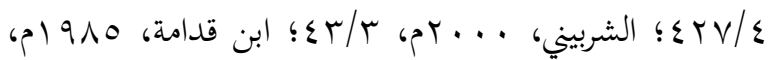


وأجازه له أخواه، فهو له. وإن أجاز له أحدهما وحده، فله ثلثاه. وإن أجازا له نصف العبد، فله نصفه، ولمما نصفه. وإن أجازا

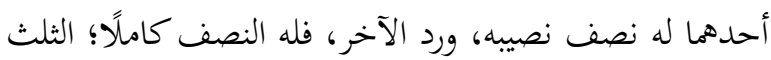
نصيبه، والسدس من نصيب الجميز، وإن أجاز كل واحد منهما له نصف نصيبه، كمل له الثلثان. وإن أجاز له أحدهما نصف نصيبه، والآخر ثلاثة أرباع نصيبه، كمل له ثلاثة أرباع العبد.

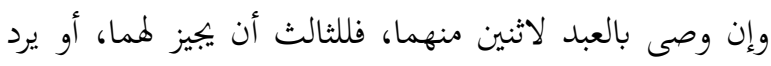

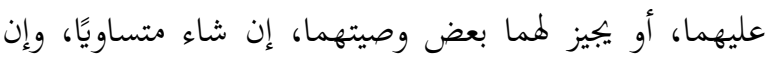
شاء متفاضلا، أو يرد على أحدهما، ويجيز للآخر وصيته كلها

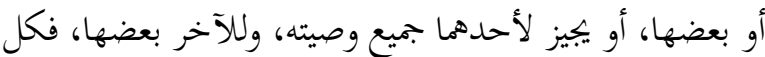
ذلك جائز؛ لأن الحق له، فكيفما شاء فعل فيه (ابن قدامة،

$$
\text { . (1 } \leqslant 7-1 \leqslant 0 / 7 \text { (p) } 910
$$

وكذلك في حالة الوصية بأكثر من الثلث لوارث، ويجيز

ذلك بعض الورثة. فمثلا: إذا ترك الرجل ابنين فأوصى لأحدهما

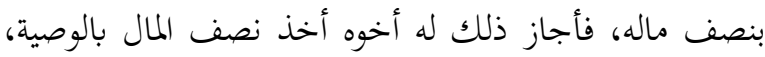

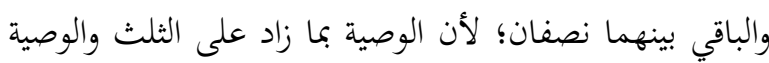
للوارث إنما تمتنع لحق الورثة، فإذا وجدت الإجازة فقد زال المانع؛ فيأخذ الموصى له نصف المال بطريق الوصية، والإرث ينبغي عن المستحق بالوصية يبقى ما له النصف الباقي، فيكون بين الاثنين

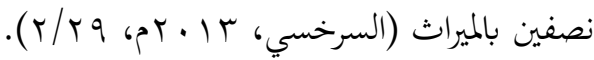
وأصحاب هذا الاتحاه يستندون إلى أدلة أهمها ما يلي: ا ـ ما ورد في رواية الدارقطني عن عمرو بن شعيب عن أبيه عن

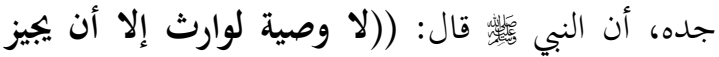

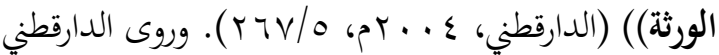
عن ابن عباس أن رسول الله

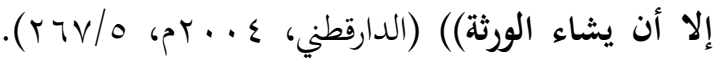
وبناء على هذا الاستثناء، فتعتبر الوصية للوارث صحيحة ونافذة إذا أجازها بقية الورثة وهم أهل لذلك (الشوكاني،

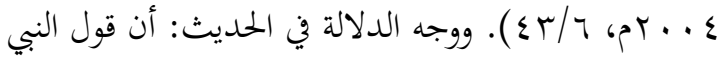

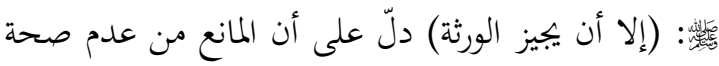

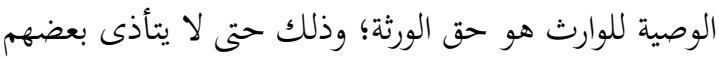

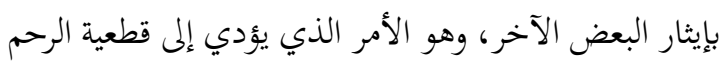

المطلب الثاني: الوصية للوارث صحيحة بإجازة الورثة

ذهب الحنفية والشافعية في الأظهر والحنابلة في الراجح من رن مذهبهم، وبعض المالكية، إلى أن الوصية صحيحة غير نافذة،

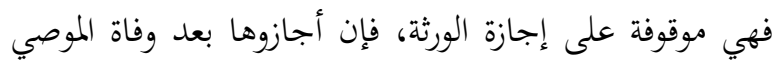
صحّت ونُفذت، وإلاً فتبطل. وبيان ذلك كما يلي: قال الحنفية ولو أوصى لبعض ورثته فأجاز الباقون جازت

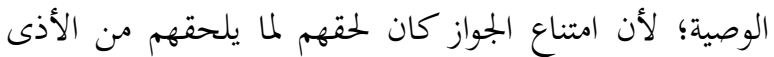
والوحشية بإيثار البعض، وفي بعض الروايات: (لا وصية لوارث

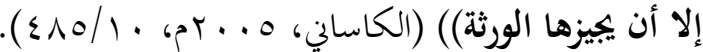
والقول الأظهر للشافعي مفاده صحة الوصية للوارث؛ لما روى ابن عباس، أن النبي

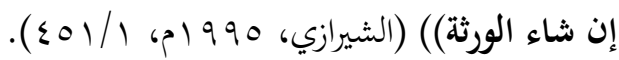
وقال الحنابلة لا وصية لوارث إلا أن يجيز الورثة (ابن

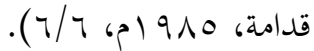
وهذا قول عند المالكية، كما في "بداية المجتهد": الوصية للوارث صحيحة إذا أجازها الورثة بعد الموت (ابن رشد،

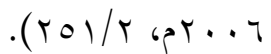

وبعبارة أخرى، فالأصل في الوصية ألا تكون

لوارث، فإن أوصى شخص لوارث توقفت صحة هذه الوصية على إجازة الورثة، فإن أجاز الجميع الوصية نفذت. وإن أجازها

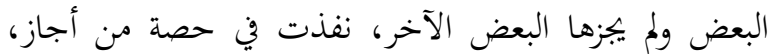

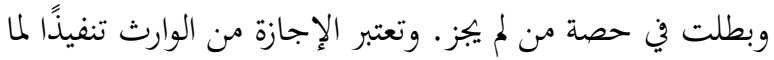

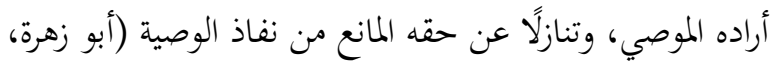

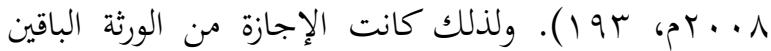
ضرورية لصحة هذه الوصية؛ لدفع الضرر عنهم جميعًا (السريتي، .(7) 6 $6199 \mathrm{~V}$

فعلى سبيل المثال، في حالة إذا وصَّى لوارث، وأجاز بعض باقي الورثة الوصية دون البعض، نفذ في نصيب من أجاز، دون من لم يجز. ـ وإن أجازوا بعض الوصية دون بعض، نفذت فيما أجازوا دون ما لم يجيزوا. فإن أجاز بعضهم بعض الوصية، وأجاز بعضهم جميعها، أو ردها، فهو على ما فعلوا من ذلك. فلو خلف ثلاثة بنين وعبدًا، لا يملك غيره، فوصى به لأحدهم، 
المطلب الثالث: الوصية للوارث صحيحة سواء أجازها

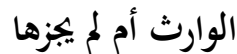
ذهب الشيعة الإمامية، وفريق من الشيعة الزيدية إلى جواز الوصية

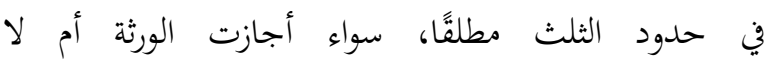

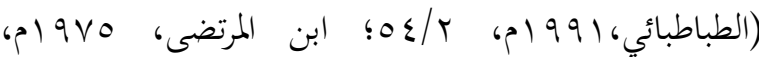

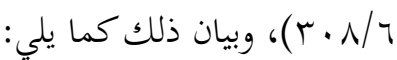

قالت الشيعة الإمامية في "الروضة البهية": "وتستحب الوصية لذوي القرابة وارثًا كان أم غير وارث؛ لعموم قوله تعالى:

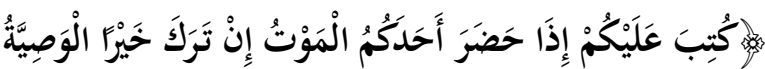

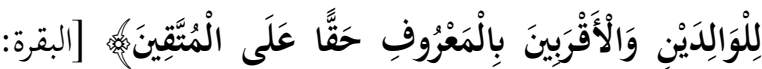

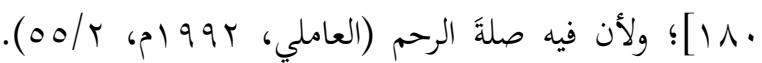
ووجه الدلالة في الآية الكريمة: أها أجازت مشروعية الوصية للورثة

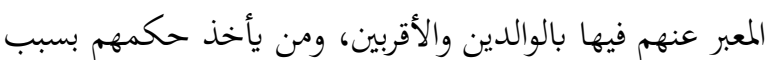

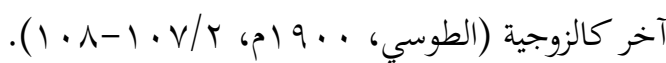
والشيخ المفيد يقول في كتابه "المقنعة": "ولا بأس بالوصية

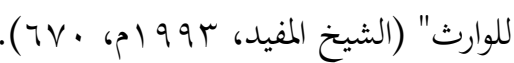
كما جاء في "الانتصار"، حيث يذكر الشريف المرتضى

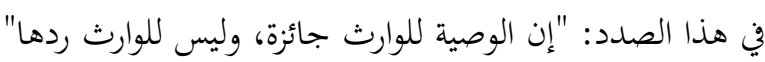

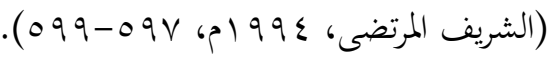
ويذكر الحلي في "المختصر النافع": "وتصح الوصية

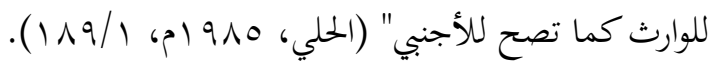
وفي كتاب "المبسوط" في فقه الإمامية: "وعندنا يرث؛

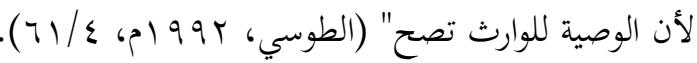
كما ذهب هذا المذهب بعض الزيدية، منهم العباس بن أحمد، حيث يقول: "حق الورثة في ثلثي التركة، أما الثلث فهو

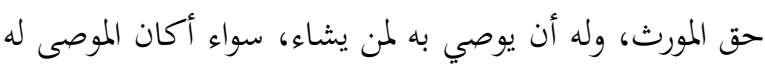

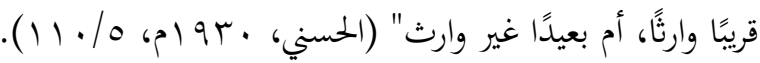
قال الإمام الشوكاني في نيل الأوطار: "قال بعض الشيعة

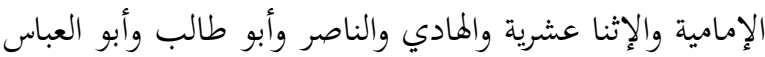

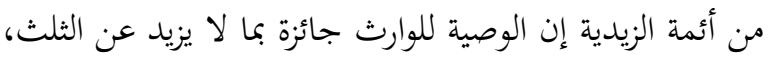

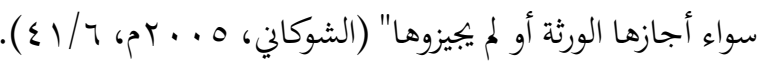

التي أمر الله -تعالى - بوصلها، فإذا أجازوها وكانوا من أهل الإجازة شرعًا، فقد رضوا بإسقاط حقهم فارتفع المانع؛ ومن لمن

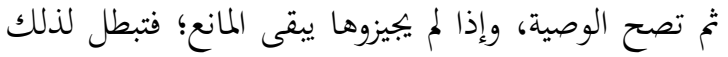

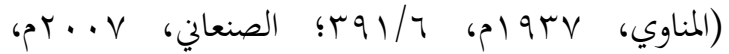
.$(107 / \mathrm{r}$ r ـ ولأن المنع كان لحقهم فتجوز بإجازعم؛ لأغم بإجازهم قد

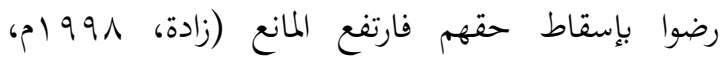

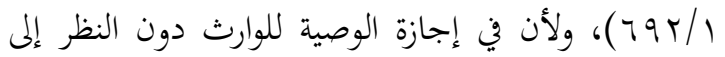
إجازقم فيه إيذاء لهم بإيثار الموصى له عليهم؛ مما يسبب إيقاع العداوة والحسد وقطعية الرحم بينهم (المرغيناني،

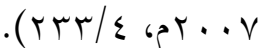
r. واستدل هذا الفريق بالقياس، حيث قالوا: إن الأجنبي تصح له الوصية بزيادة على ثلث التركة؛ لأن الإيصاء إليه لا يثير

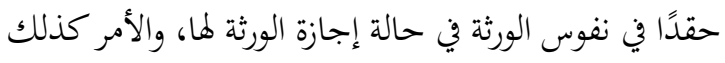
بالنسبة للوارث، إذا قبل الورثة الوصية وأجازوها. ولأن الإيصاء بما زاد على الثلث غهى عنه. وقد اتفق على أن النهي مخصوص، فإذا أجاز الورثة الوصية للأجنبي منا زاد عن لن

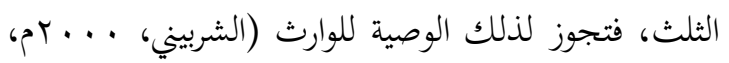
r/ץ

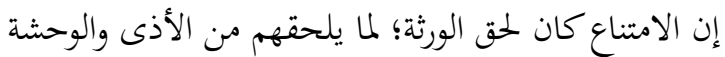
بإيثار البعض، ولا يوجد ذلك عند الإجازة (الكاساني،

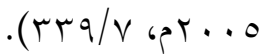
لكن اشترط هذا الفريق لصحة الإجازة شرطين: ا ـ أن يكون المجيز عاقلاً بالغًا غير محجور عليه بسفه أو عته

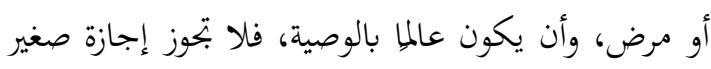

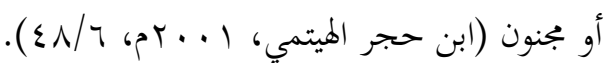
r. أن تكون الإجازة بعد موت الموصي، فلا عبرة بإجازة الورثة حال حياة الموصي. فلو أجازوها حال حياته، ثم ردوها بعد

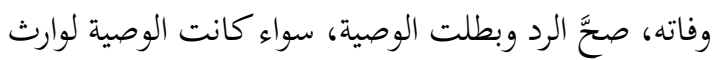

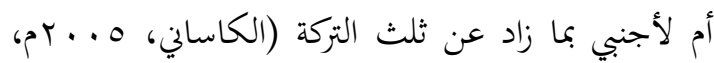

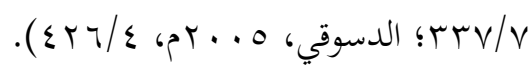




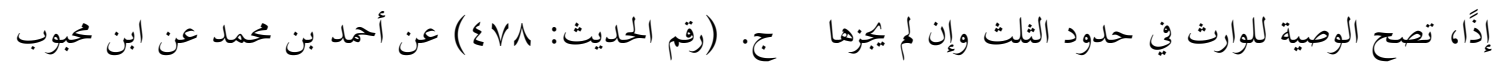
عن أبي ولاد الحناط قال: سألت أبا عبد الله عليه السلام

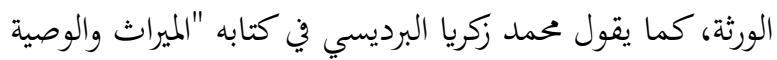
عن الميت يوصي للبنت بشيء، قال: "جائز ".

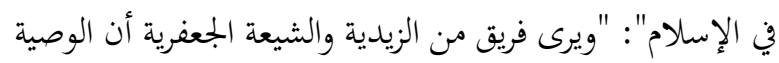

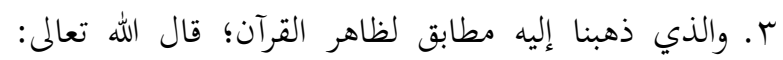

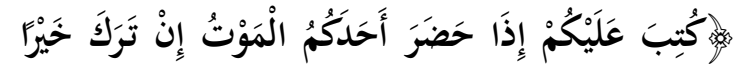

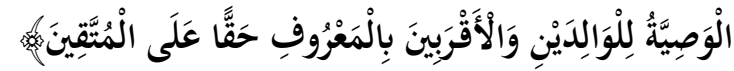

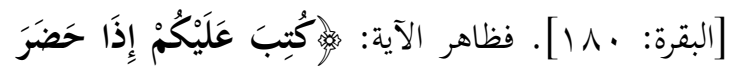

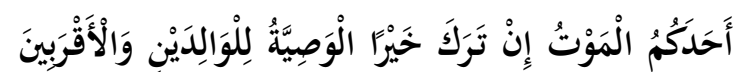

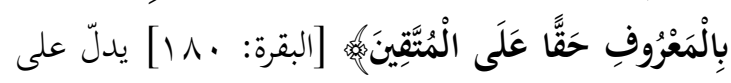

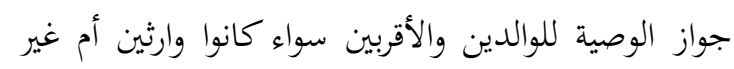
وارثين، وهم يقولون: إن الآية محكمة غير منسوخة، تمح قالوا هذا هو الحق الثابت والعدل الذي لا شك فيك فيه؛ ومن أجل إله

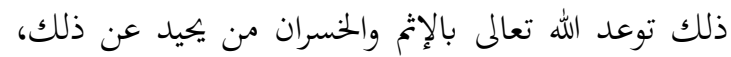

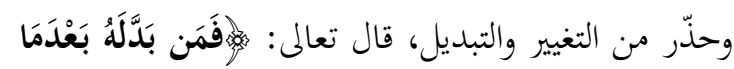

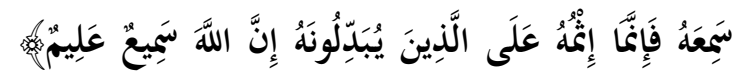

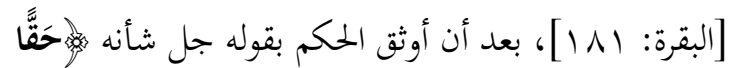

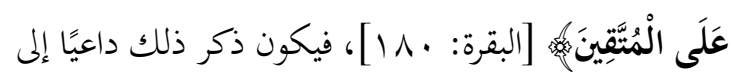
طاعته (السيستاني،

$$
\text { .(1) (1)-11./r r a } 9 \text {. . }
$$

ع. وقالوا: إن التصرف في الوصية للوارث قد صدر من أهله

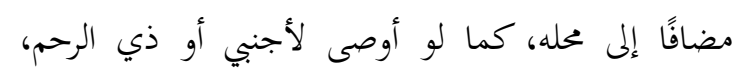

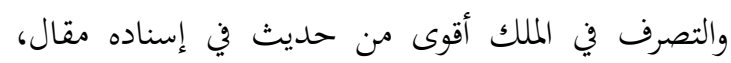
ويعنون به حديث ((لا وصية لوارث إلا أن يجيز الورثة))

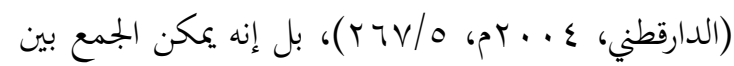

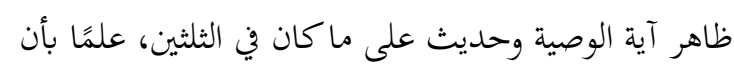

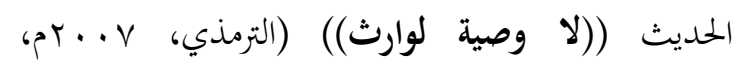

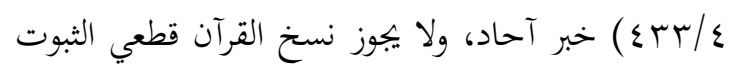

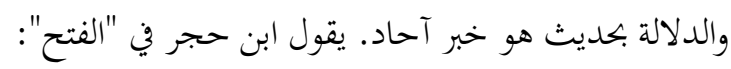

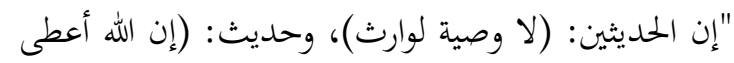
كل ذي حق حقه) لا يخلو إسناد كل منهما عن مقال

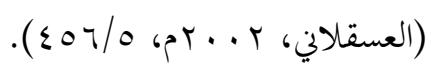
للوارث ولأجنبي في الحكم سواء؛ فتصح الوصية للوارث، كما

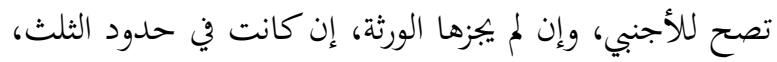

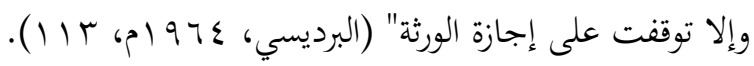
واستدل أصحاب هذا المذهب بما يلي:

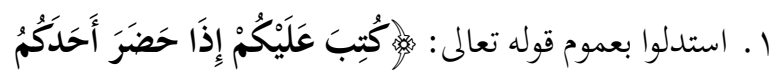

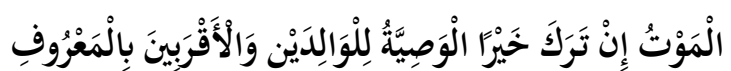

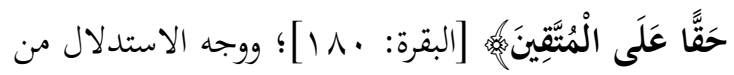
الآية الكريمة: أن الوصية جائزة للوارث؛ لأن قال الله

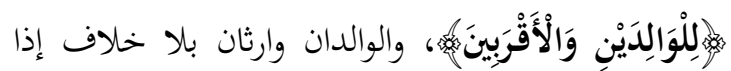

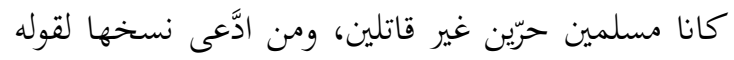

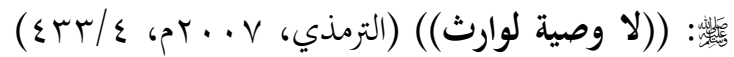
فقد أبعد؛ لأنه خبر واحد، لا يجوز نسخ القرآن به إجماعًا، وعندنا لا يجوز العمل به في تخصيص عموم القرآن (الطوسي،

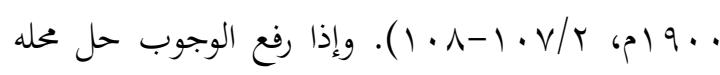
الجواز؛ وبناء على ذلك فإن قول رسول الله لوارث) يعني نفي الوجوب لا الجواز، أي: أها لم تبق واجبة وله

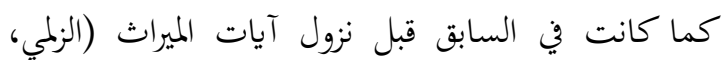

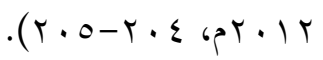

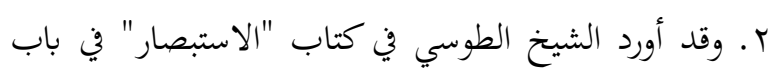

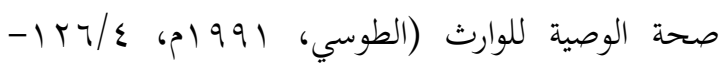

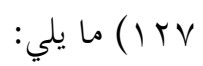
أ. (رقم الحديث: عVT ) عن الحسين بن سعيد عن الحسن بن علي وفضالة عن عبد الله بن بكير عن محمد بن مسلم قال: سألت أبا عبد الله عليه السلام عن الوصية للوارث، فقال:

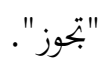

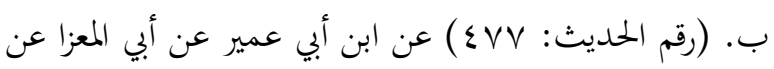

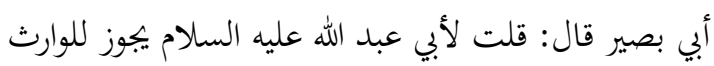

$$
\text { وصيته؟ قال: "نعم". }
$$

ه. واستدلوا بظاهر حديث النبي

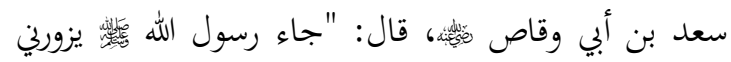


النفاذ، فتعتبر الوصية للوارث صحيحة ونافذة إذا أجازها بقية الورثة، وعلى هذا فلا يصح هذا الاستدلال (الشوكاني،

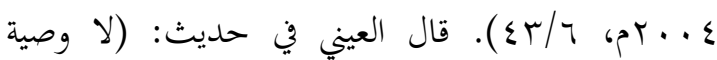

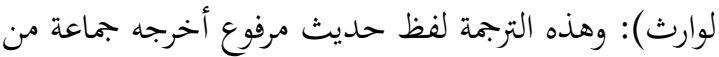
الصحابة والتابعين، ولم يروه البخاري؛ لأنه ليس على شرطه،

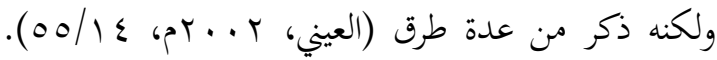
فجنح الشافعي في "الأم" إلى أن هذا المتن متواتر، فقال:

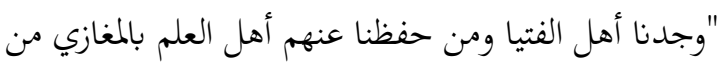

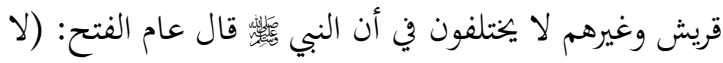
وصية لوارث)، ويؤثرون عمن حفظوه عنه ممن لقوه من أهل العلم، فكان نقل كافة عن كافة، فهو أقوى من نقل واحد

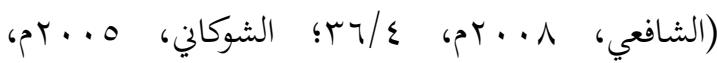

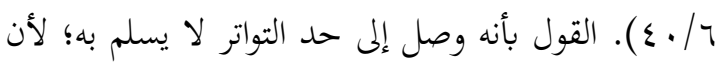

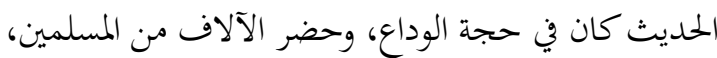

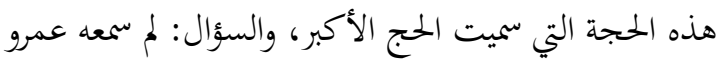
بن خارجة ولم يسمعه غيره من المسلمين الذين حضروا الحج

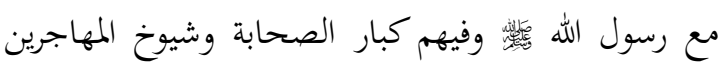

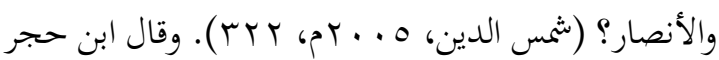

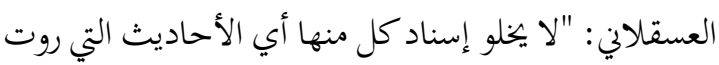

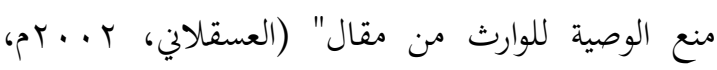

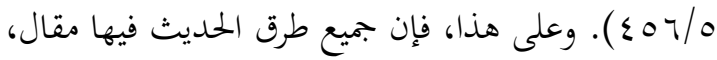
ولا تصلح لأن تعارض القرآن الكريم أو تكون ناسخة لهاله،

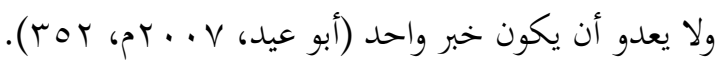

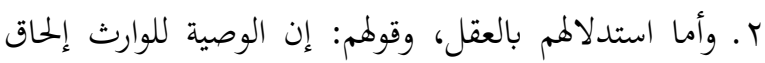
الضرر، وتقطع الرحم، وتوجب العداوة والبغضاء بين أفراد

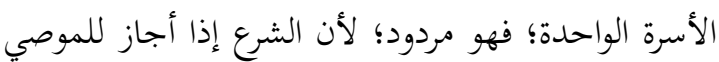

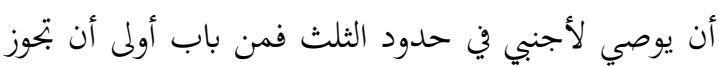

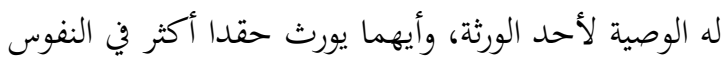

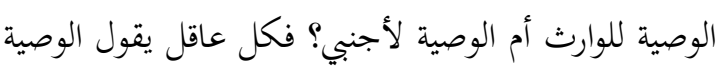

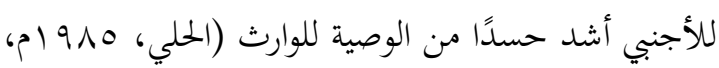
.$(119 / 1$ r. وأما قولمم إن عدالة الإسلام توجب الالتزام بما جاء في

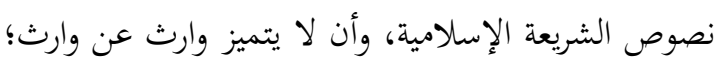

عام حجة الوداع من وجع اشتد بي فقلت: يا رسول الله، قد

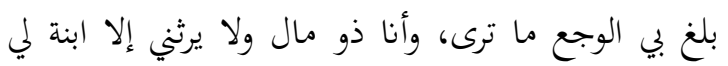

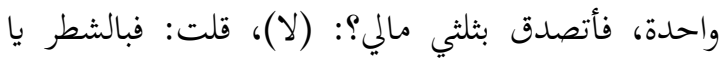
رسول الل؟ قال: (لا)، قلت: فبالثلث، قال: ((الثلث والثلث كثير؛ إنك إن تذر ورثتك أغنياء خير من أن تدعهم عالة يتكففون الناس في أيديهم)) (البخاري،

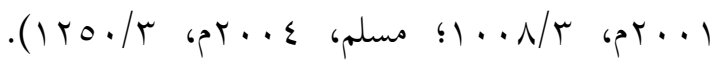
ودلالة الحديث واضحة على جواز التصرف بالثلث من التركة، والثلثين حق للورثة فقط، وما بقي للموصي أن ودئ

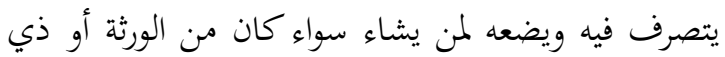

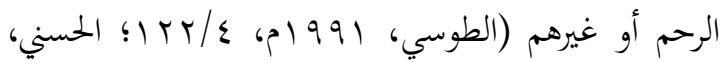
.).

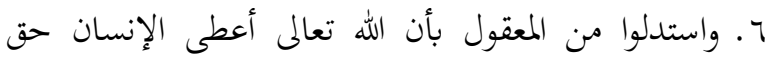
التصرف في ثلث ماله عند وفاته يضعه كيفما يشاء، فمن

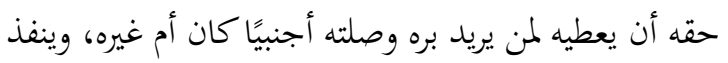
من غير توقف على إجازة أحد، بل وصيته للوارث أولى إذا

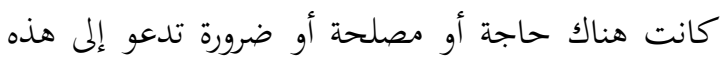

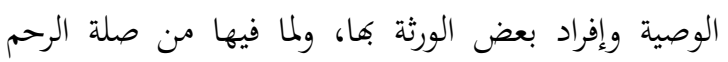

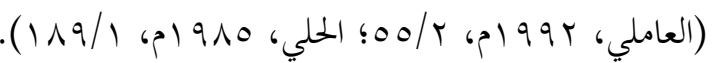

\section{المبحث الرابع : مناقشة أدلة الفقهاء مع بيان الرأي الراجح}

المطلب الأول: مناقشة أدلة من منع الوصية للوارث مطلقًا ذهب ابن حزم، والمالكية، وبعض الشافعية، وبعض الحنابلة إلى أنه لا بجوز الوصية للوارث مطلقًا. وناقش العلماء أدلة هذا القول

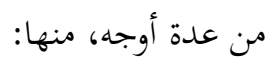
1 ـ أما استدلالهم بحديث ((إن الله قد أعطى كل ذي حق حقه

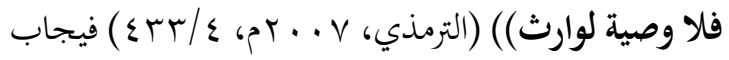

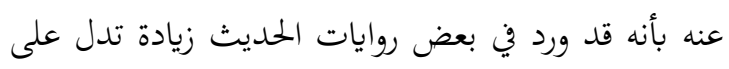
صحة الوصية، ففي بعض طرقه: (لا وصية لوارث إلا أن يجيز الورثة)، أو (لا تجوز وصية لوارث إلا أن يشاء الورثة)

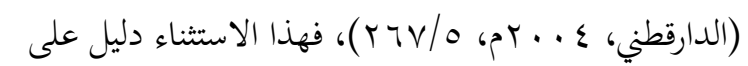
أن الصحة ليست منتفية، بل المنتفي شيء وراءها وهو 
طرق أخرى عن جماعة آخرين من الصحابة، بعضها صحيح

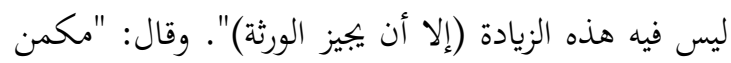
الخطر في الحمديث هي حصيلة التساهل في النقل دون إمعان

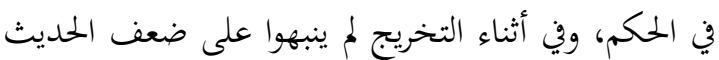

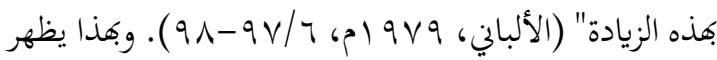
أن هذه الزيادة غير صحيحة، ولا تصلح للاحتجاج بها في النياتي إثبات الوصية للوارث إن أجازها الورثة، وهل تصلح مثل

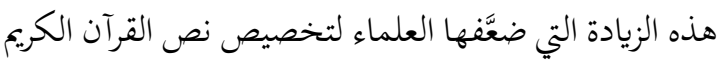
في آية الوصية، وهي قطعية الثبوت قطعية الدلالة على جواز

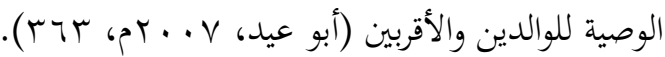

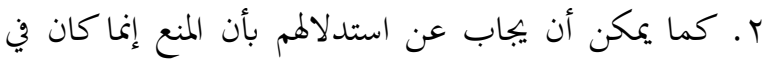
الأصل لحق الورثة، فإن أسقطوا حقهم زال المانع بأن هذا بـان الاستدلال بأن الإجازة إن تمت فهي مض هض هبة، لا تعطى اسطى

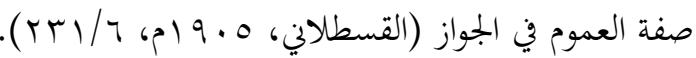
r. وأما قولم بأنه لو أوصى لأجنبي بأكثر من الثلث وأجاز الورثة جازت؛ فالوصية للوارث مثل ذلك، فيجاب عن ذلك بأنه قياس في مواجهة نص (لا وصية لوارث) (النمري، . (rTV/V r r T...

المطلب الثالث: مناقشة أدلة من أجاز الوصية للوارث مطلقًا ذهب الشيعة الإمامية وبعض الزيدية إلى القول بمشروعية الوصية

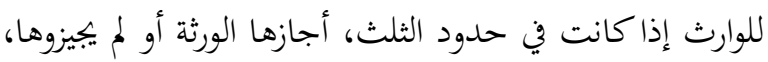
ومناقشة أدلتهم كما يلي: 1. استدلوا على مذهبهم بأن نسخ الوجوب في قوله تعالى:

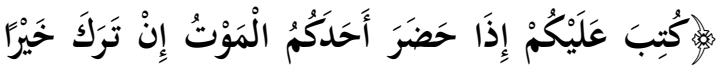

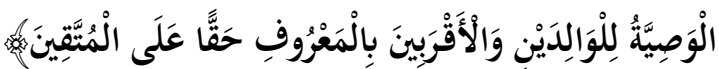

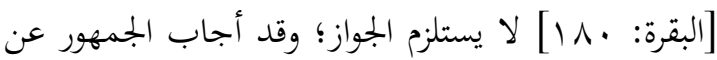

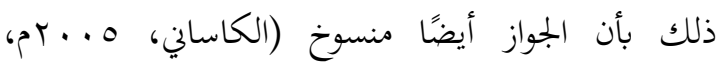

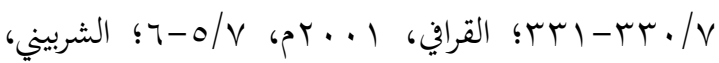

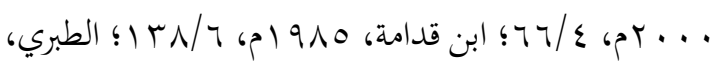

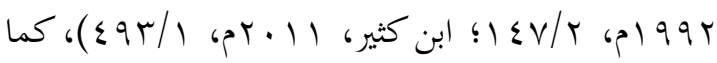
صرح بذلك حديث ابن عباس، وحديث عمرو بن شعيب.
فيجاب عن ذلك أن حق الورثة محفوظ ولا تعدي على

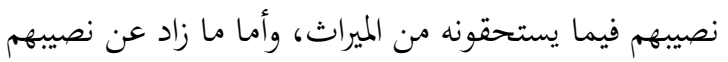
وهو الثلث، فمن حق المورث أن يضعه حيث يشاء، لوارث

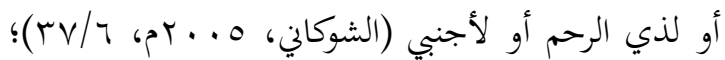
لقول النبي

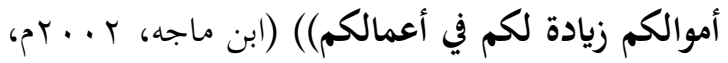
.$(q \cdot \varepsilon / r$

المطلب الثاني: مناقشة أدلة من أجاز الوصية للوارث بإجازة

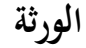

إن الوصية للوارث صحيحة إذا أجازها الورثة بعد الموت، وهذا ما ذهب إليه الحنفية، والشافعية في الأظهر، والحنابلة في الراجح من مذهبهم، وبعض المالكية، ومناقشة أدلتهم كما يلي: ا ـ أما الاستدلال بالاستثناء الوارد في حديث ((لا تجوز وصية

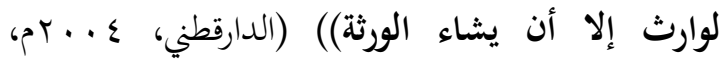

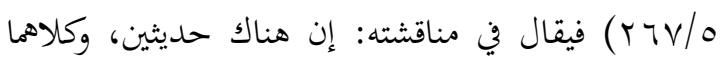
رواهما الدارقطني. فإسناد كل منهما فيه ضعف، فحديث عمرو بن شعيب قال فيه ابن حجر: "إسناده واه، وعمرو بن شعيب عن أبيه عن جده إسناد مختلف فيه عند أئمة

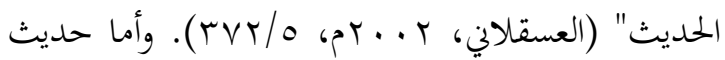
ابن عباس فهو مرسل؛ فقد قيل: إن عطاء الذي رواه عن

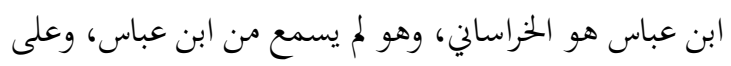
تقدير عطاء بن أبي رباح فهو مرسل كذلك (الزيلعي،

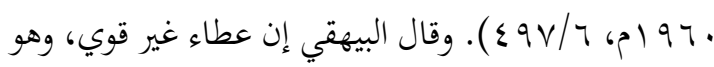

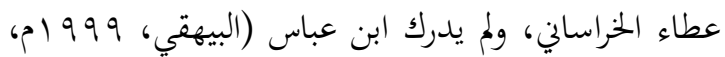

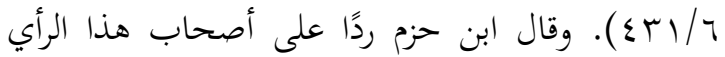

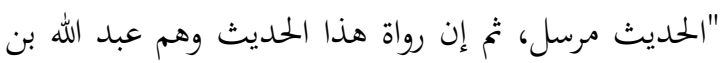

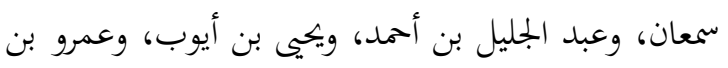

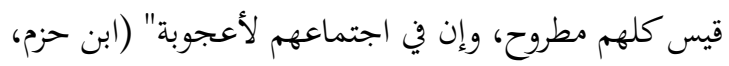

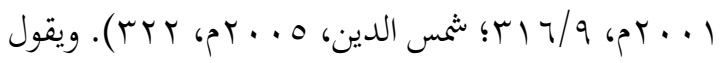

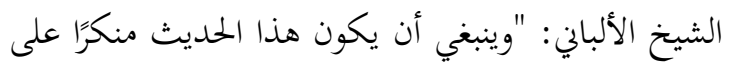
ما تقتضيه القواعد الحديثية، أضف إلى ذلك أنه جاء من 
• ب9 (م) م/ / / 1)؛ فأجيب عنه بأن هذا مقيد بحديث.

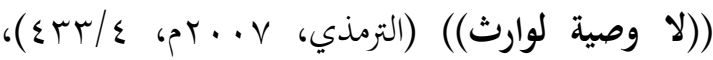

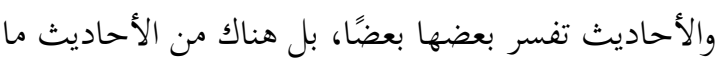

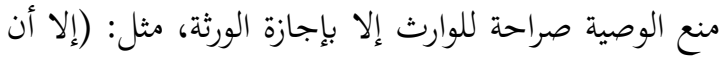

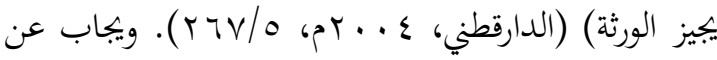

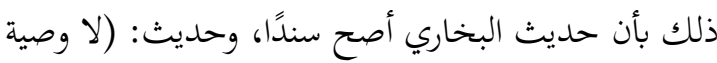

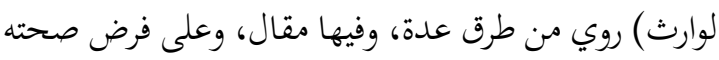

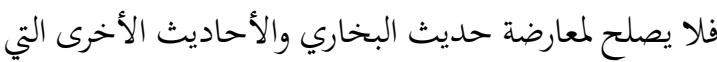

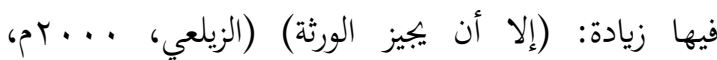
. ـ. وأما القول بأن الوصية للوارث قد تدعو إليه حاجة وفيه صلة

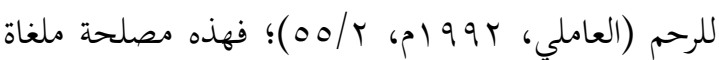
بالحديث، ولا اجتهاد في مورد النص، ثم إن هذه المصلحة لا تقوى على مناهضة الضرر الذي يترتب على الوصية

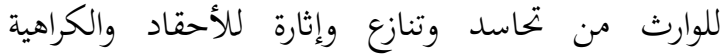
والضغائن، مع احتمال تعسف الموصي واتباع الهوى والمحاباة.

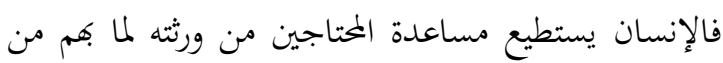

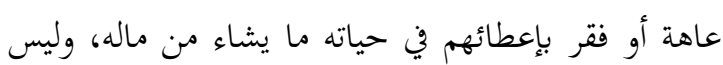

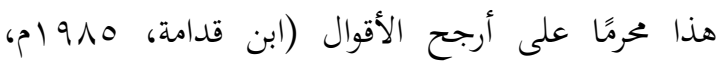

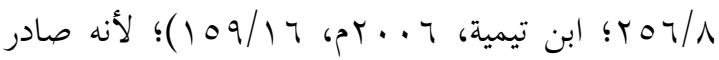
بقصد الإحسان والمواساة، لا بقصد التفضيل والمحاباة (أبو

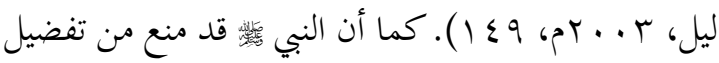
بعض الولد على بعض في حال الصحة وقوة الملك، وإمكان

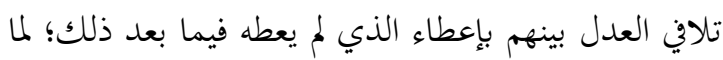
فيه من إيقاع العداوة والحسد بينهم، ففي حال موته، ومرضه، وضعف ملكه، وتعلق الحقوق به، وتعذر تلافي العدل بينهم

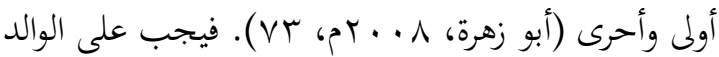

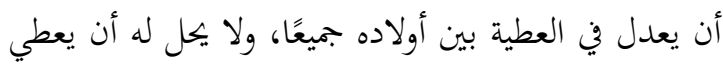

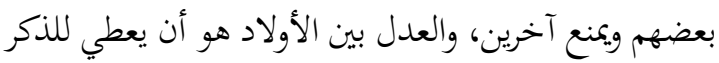

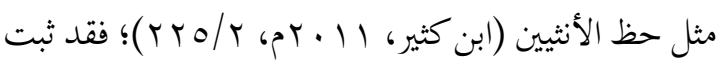
عن النبي (بس أنه قال: ((اتقوا الله، واعدلوا بين أولادكم))

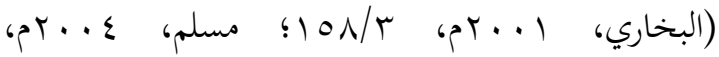
r/r/r T ( )، والحديث يدلّ على طلب التسوية بين الأولاد
ووجه الدلالة: أن الحديث علَّق صحة الوصية للوارث على إجازة الورثة، والاستثناء من النفي إثبات، فتتبت صحة

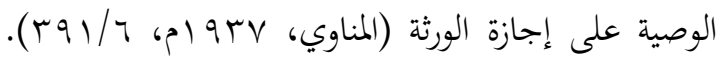

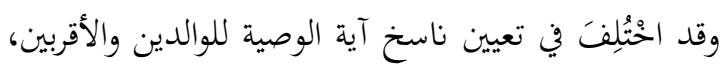

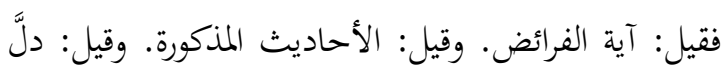
الإجماع على ذلك، وإن لم يتعين دليله. وقد رُوِّحَ أن الآية خصوصة؛ لأن الأقربين أعم من أن يكونوا وارثين أم لا، فكانت الوصية واجبة لجميعهم، وخصّ منها الوارث بآية الفرائض وبالأحاديث، وبقي حق من لا يرث من الأقربين من الوصية على حاله، قاله طاووس وغيره (الشوكاني،

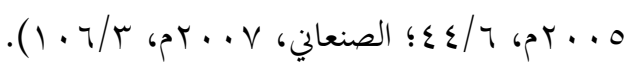

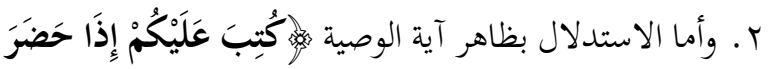

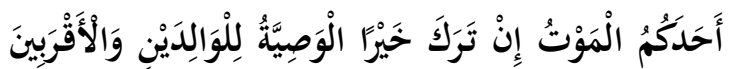

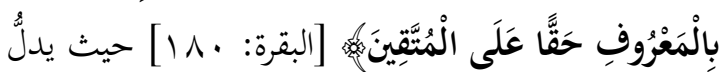

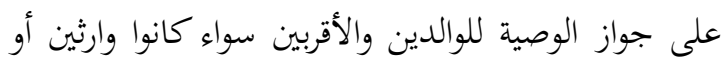

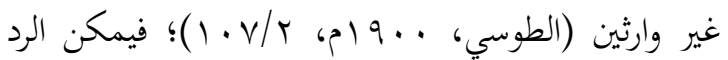

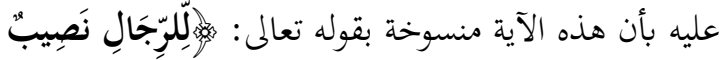

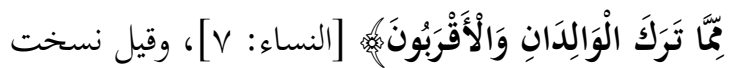

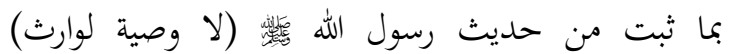

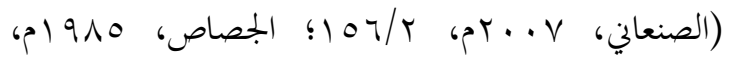

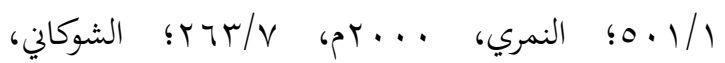

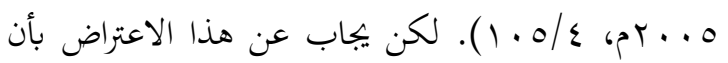
القول بالنسخ غير مسلم وغير متفق عليه بين العلماء، سواء كان بآية المواريث أو بالحديث؛ لأن الحديث خبر آحاد لا يفيد إلا الظن. وكما قال الإمام الشافعي: لا يصح نسخ

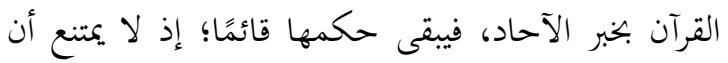
يستحق الإنسان بالوصية وبالوراثة في وقت واحد من مال واحد، فالوراثة من جعل الله تعالى، والوصية من جعل الموصي

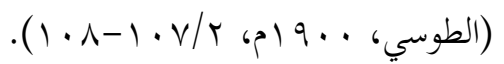

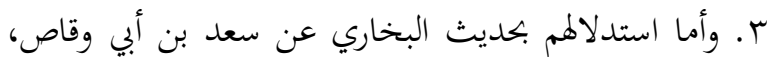

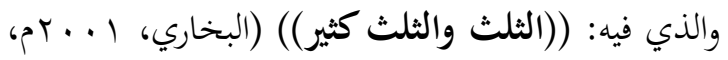
r/ r/ . 1 ) حيث يدلّ على جواز تصرف الموصي في ثلث

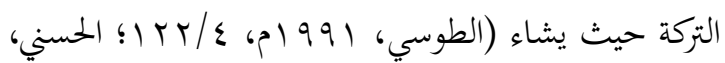




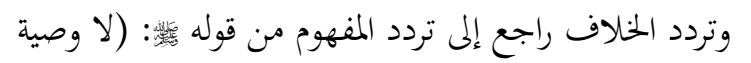

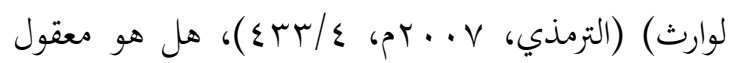

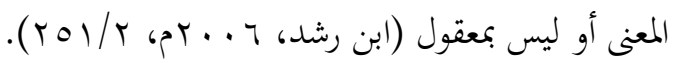
بعد عرض مذاهب الفقهاء في حكم الوصية للوارث

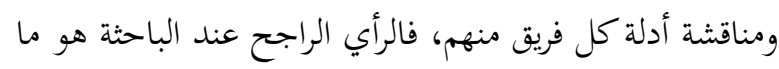

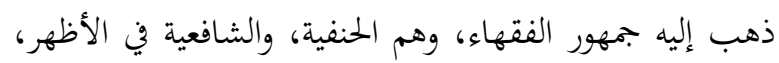

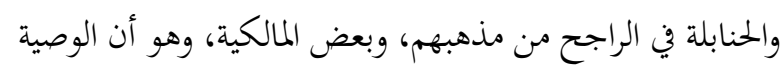

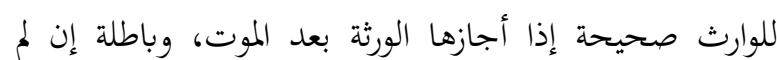

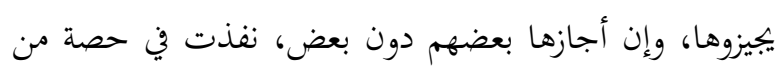

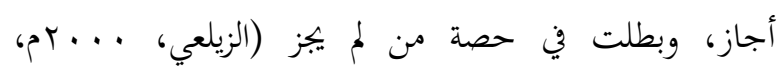

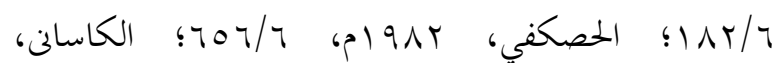
ـ

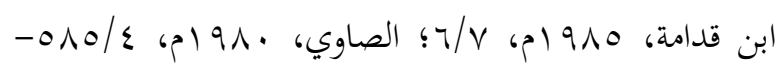
.$(0 \wedge 7$

وتعتبر الإجازة من الوارث تنفيذًا لما أراده الموصي، وتنازلًا عن حقه المانع من نفاذ الوصية، فالإجازة من الورثة الباقين ضرورية لصحة هذه الوصية؛ لدفع الضرر عنهم جميعًا (السريتي،

.(7) 6 $9199 \mathrm{~V}$

واستدل فريق هذا المذهب بحديث رسول الله

وصية لوارث إلا أن يجيز الورثة))، وفي رواية أخرى ((لا تجوز

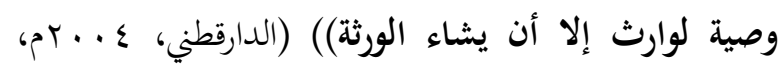
ال

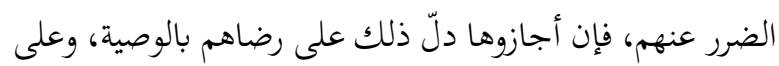

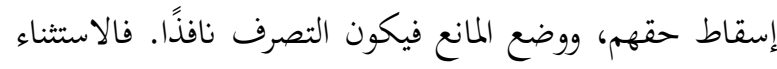
في الحديث يعتبر أن الوصية للوارث صحيحة ونافذة إذا أجازها بقية الورثة وهم أهل لذلك، بأن يكون المجيز من أهل التبرع عالميا

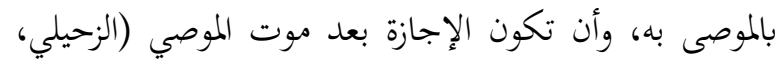

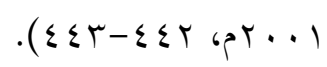

ومن جانب آخر، فإن القول بجواز الوصية للوارث في

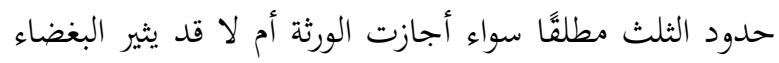

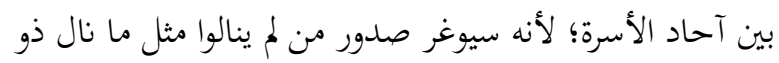
الحظوة، وإنه لن يكون سبيل عدل، بل سيكون في أكثر أحواله
في الهبات؛ لأن التفضيل يؤدي إلى الإيحاش والتباغض

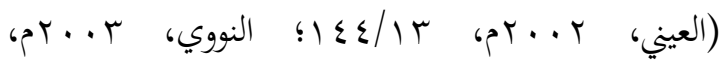
| للوالد أن يخص بعض أولاده بشيء إلا برضا الباقين المكلفين

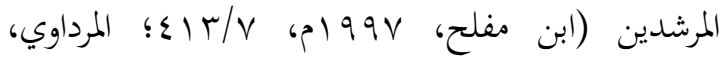
(1. $1 / \mathrm{V}$ ср $199 \mathrm{~V}$ ه. جاء في كتاب "حجة الله البالغة": "ولما كان الناس في الجاهلية يضارُّون في الوصية، ولا يتبعون في ذلك الحكمة لهمة الواجبة، فمنهم من ترك الأحق والأوجب مواساته، واختار الأبعد برأيه الأبتر، وجب أن يسد هذا الباب، ووجب عند عند

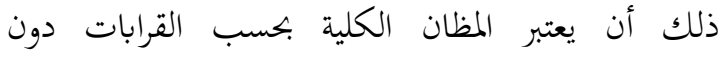

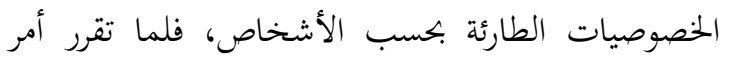

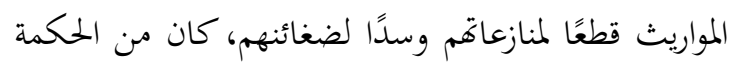
أن لا تسوغ الوصية لوارث؛ إذ في ذلك مناقضة للحد

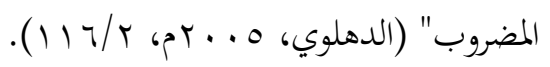

المطلب الرابع: الرأي الراجح وقبل بيان الرأي الراجح، يحسن بالباحثين توضيح سبب الخلاف في المسألة، وهو ما يرجع إلى عدة أمور، منها: 1. التعارض الظاهر بين نصوص الكتاب والسنة، فنصوص

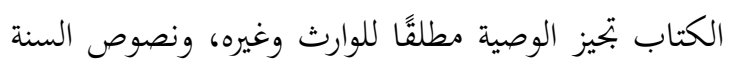

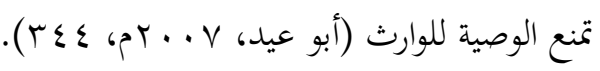

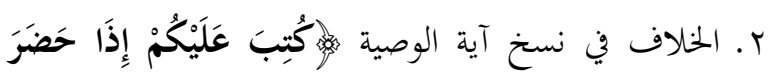

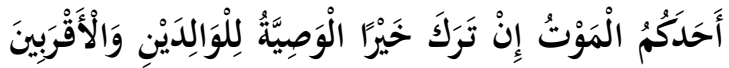

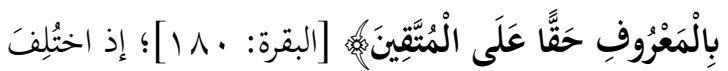
هل هذه الآية محكمة أو منسوخة؟ فمن قال إنا محكمة

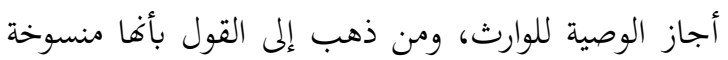

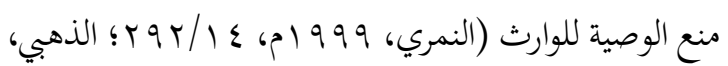
. ( $1 \leqslant N / t$ a r. ثم هل المنع لحق الورثة أو أنه أمر تعبدي، فمن قال إنه أمر تعبدي لا بجوز مخالفته قال بأنه لا تجوز الوصية وإن أجازها

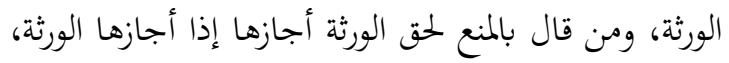


بإيثار البعض. فسبب حظر الوصية للوارث هو ما يلحق بالورثة من الضرر وما يحدث من الحقد والشعور بالتفريق والتمييز • وإن هذا السبب غير قائم في حالة إجازة بقية الورثة بعد وفاة الموصي وهم أهل لهذه الإجازة عندئذ.

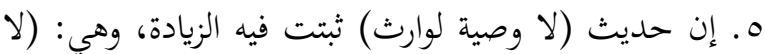
وصية لوارث إلا أن يجيز الورثة)، وفي بعض الروايات: (لا لا

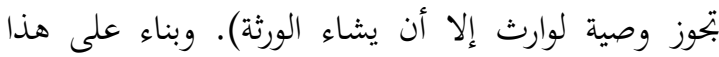
الاستثناء، تعتبر الوصية للوارث صحيحة ونافذة إذا أجازها بقية الورثة المؤهلين. وإن المانع من عدم صحة الوصية للوارث هو حق الورثة؛ حتى لا يتأذى بعضهم بإيثار البعض الآخر،

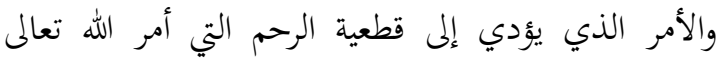

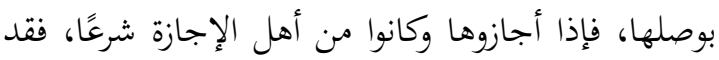
رضوا بإسقاط حقهم فارتفع المانع؛ ومن ثم تصح الوصية، وإذا لم يجيزوها يبقى المانع فتبطل لذلك. ليك.

7. الذي ترجح لدى الباحثين هو القول الثاني للحديث المستدل

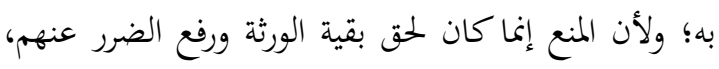
فإن هم أسقطوا حقهم وأجازوا الوصية صحت لزوال المانع. لذلك، فالاعتماد على مذهب الجمهور بأن الوصية للوارث تقع صحيحة وتعتبر نافذة بإجازة الورثة هو الأصوب؛ لقوة أدلتهم، وحرصهم على وحدة صف ورثة المتوفى، وتآلفهم وصلة الرحم.

\section{المراجع}

Abū Layl, Maḥmūd Aḥmad. 2003. Al-Wașāyā wa al-Waqf fĩ alSharī'ah al-Islāmiyyah. Al-Imārāt al-'Arabiyyah al-Muttahidah: Jāmi'ah al-Imārāt al-'Arabiyyah al-Muttahidah.

Abu 'Ayd, 'Ārif. 2007. Al-Wașiyyah Li al-Wārith bayna alHazor wa al-Ibāḥah. Jāmi'ah Qațar: Majallah 'Ilmiyyah Muhakkamah.

Abu Zahrah, Muhammad. 2008. Sharaḥ Qānūn al-Wașiyyah Dirāsah Muqāranah Li Masā'iluhu wa Bayān Li Mașādiruhu alFiqhiyyah. Al-Qāhirah: Maktabah Al-Anjilū al-Mișriyyah.

Al-'Asqalānī, Ahmad bin 'Alī bin Hajar. 2002. Fath al-Bārī Sharḥ Șoḥị̣ al-Bukhārī. Al-Qāhirah: Dār al-Muhaddithīn.

Al-‘Aynī, Badr al-Dīn Maḥmūd bin Aḥmad. 2002. 'Umdah alQārī Sharḥ Șoḥị̣ al-Bukhārī. Bayrūt: Dār al- Fikr.

Al-‘Āmilī, Muhammad bin Jamāl al-Dīn al-Makkī (Al-Shahīd al-Awwal), Zayn al-Dīn al-Jib‘í (Al-Shahīd al-Thānī). 1992. AlRawḍoh al-Bahiyyah. Bayrūt: Manshūrāt Mu'assasah al-A'lamī Li al-Maṭbū'āt.
لغير العدل، ولغير ذي الحاجة، واعتبر ذلك بالأوقاف التي استخدمت لمحاباة بعض الورثة، أو العقود التي كانت في حقيقتها لئها

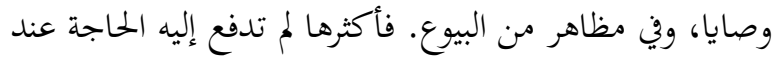

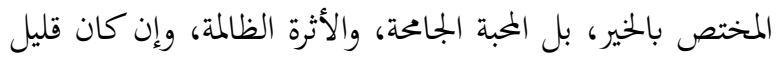

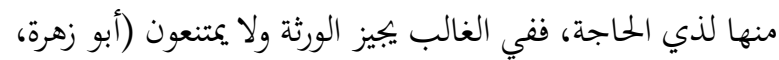

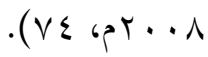

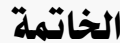

لقد استتنج الباحثون عدة نتائج منبثقة عن الدراسة، يمكن إبراز

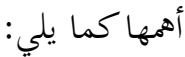
1 ا ـ اختلف الفقهاء في حكم الوصية للوارث على عدة مذاهب،

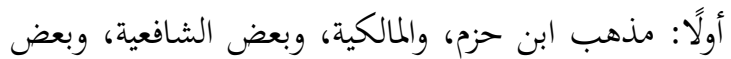

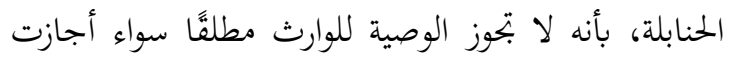

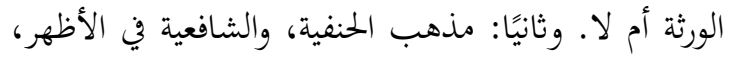

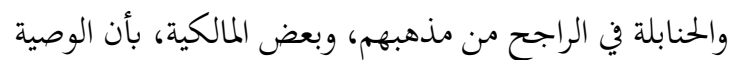
للوارث صحيحة إذا أجازها الورثة بعد وفاة الموصي. وثلثانثا:

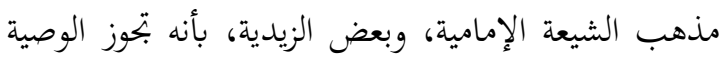
للوارث في حدود الثلث مطلقًا سواء أجازت الورثة أم لا. لا. r. ذهب جمهور الفقهاء إلى أنه تنفذ الوصية للوارث بالإجازة

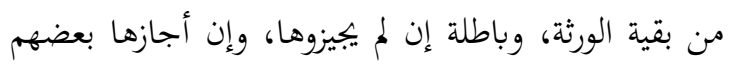

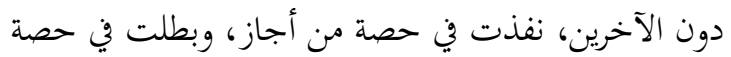
من لم ميزز . ويشترط لصحة الإجازة بأن يكون الجيز من أهل الهاري

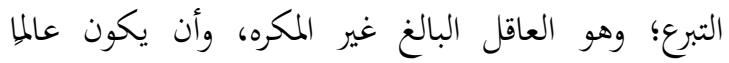
بالوصية، وأن تكون الإجازة بعد وفاة الموصي.

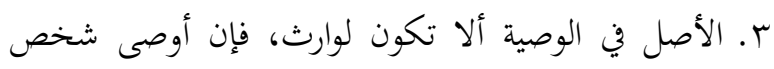
لوارث توقفت صحة هذه الوصية على إجازة بقية الورثة ولو

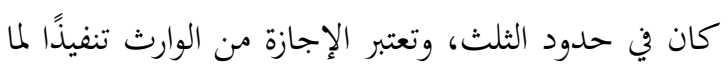

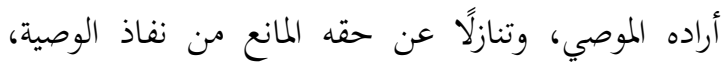

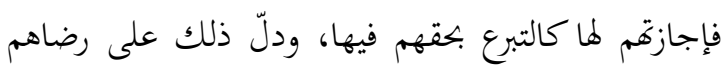
بالوصية، وعلى إسقاط حقهم في الميراث.

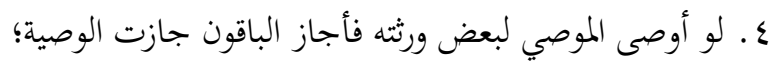

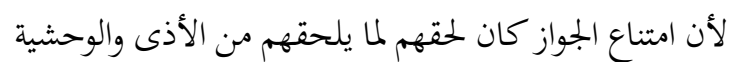


Al-Nimrī, Abū 'Amrū Yūsuf bin 'Abd al-Bar. 2000. AlIstidhkār. Bayrūt: Dār al-Kutub al-'Ilmiyyah.

Al-Ṣāwī, Aḥmad bin Muḥammad. 1980. Ḥāshiyyah al-Ṣāwī 'alā al-Sharh al-Ṣoghīr. Bayrūt: Dār al-Jīl.

Al-Ṣin‘ānī, Muhammad bin Ismā‘îl. 2006. Bulūgh al-Marām ma‘a Subul al-Salām. Al-Riyyāụ: Maktabah al-Ma'ārif Li alNashar wa al-Tawzī‘.

- Al-Ṣin‘ānī, Muḥammad bin Ismā‘īl. 2007. Subul al-Salām. AlQāhirah: Dār al-Ḥadīth.

Al-Qarāfī, Shahāb al-Dīn. 2001. Al-Dhakhīrah. Bayrūt: Dār alKutub al-'Ilmiyyah.

Al-Qastolānī, Ahmad bin Muhammad. 1905. Irshād al-Sārī Li Sharh Ṣohịḥ al-Bukhārī. Miṣr: al-Maṭba'ah al-Kubrā alAmiriyyah.

Al-Qushayrī, Muslim bin al-Hujjāj. 2004. Sohịh al-Muslim. Bayrūt: Dār al-Kutub al-'Arabī.

Al-Sajastān̄i, Abū Dāwud Sulaymān bin al-Ash'ath. 2009. Sunan Abī Dāwud. Al-Riyyāụ: Dār al-Salām.

- Al-Sarakhsī, Shams al-Dīn. 2013. Al-Mabsūṭ. Bayrūt: Dār alNawādir.

Al-Sarītī, 'Abd al-Wadūd Muhammad. 1997. Al-Wașāyā wa alAwqāf wa al-Mawārīth fī al-Sharī‘ah al-Islāmiyyah. Bayrūt: Dār al-Nahḍoh Al-`Arabiyyah.

- $\quad$ Al-Sarțāwī, Fuād 'Abdul Lațîf. 2010. Al-Wajīz fĩ al-Wașāyā wa al-Mawārīth. 'Ammān: Dār Yāfā al-'Ilmiyyah.

Al-Sīstānī, 'Alī al-Ḥusaynī. 1992. Minhāj al-Șāliḥīn. Bayrūt: Dār al-Mu'arrikh al-'Arabī.

Al-Sharbīnī, Muhammad bin Aḥmad. 2000. Mughnī al-Muhtāj Bayrūt: Dār al-Kutub al-'Ilmiyyah.

- Al-Sharīf al-Murtaḍā, 'Ālim al-Hudā 'Alī bin al-Husīn. 1994. Al-Intișār. Iīrān: Mu'assasah al-Nashar al-Islāmī al-Tābi 'ah Li Jamā'ah al-Mudarrisīn bi Qim al-Mushrifah.

- Al-Shawkānī, Muḥammad bin 'Alī. 2004. Muntaqā al-Akhbār ma'a Nayl al-Awțār. Al-Urdun: Bayt al-Afkār al-Dawliyyah.

Al-Shawkānī, Muhammad bin 'Alī. 2005. Nayl al-Awțār. AlQāhirah: Maktabah al-Ṣofā.

Al-Shāfi ‘ī, Muhammad bin Idrīs. 2008. Al-Um. Al-Qāhirah: Dār al-Ḥadìth.

- Al-Shīrāzī, Abū Ishāq Ibrāhīm bin 'Alī. 1995. Al-Muhadhib. Bayrūt: Dār al-Kutub al-'Ilmiyyah.

- Al-Tirmidhī, Muhammad bin 'Isā. 2007. Sunan al-Tirmidhī. Damshiq: Dār Ibn Kathīr.

Al-Ṭūsī, Abū Ja‘far Muhammad bin al-Ḥasan. 1900. Al-Tibyān fĩ Tafsīr al-Qur'ān. Bayrūt: Dār Ihyā’ al-Turāth al-'Arabī.

- Al-Ṭūsī, Abī Ja‘far Muhammad bin al-Ḥasan. 1992. Al-Mabsūt fī Fiqh al-Imāmiyyah. Bayrūt: Dār al-Kitāb al-Islāmī.

- $\quad$ Al-Ṭūsī, Muḥammad bin Hasan. 1991. Al-Istibṣār. Iīrān: Dār alKutub al-'Ilmiyyah.

- Al-Ṭibāṭibā'ī, Sayyīd 'Alī. 1991. Riyyāọ al-Masā’il. Iīrān: Mu'assasah Li al-Nashar al-Islāmī al-Tābi'ah Li Jamā'ah alMudarrisin bi Qim al-Mushrifah.

- Al-Ṭobarī, Muhammad bin Jarīr. 1992. Tafsīr al-Ṭobarī. Bayrūt: Dār al-Kutub al-'Ilmiyyah.

Al-Zayla'ī, Fakhr al-Dīn 'Uthmān bin Ālī. 2000. Tibyāin alḤaqā'iq. Bayrūt: Dār al-Kutub al-'Ilmiyyah.

Al-Zayla'ī, Jamāl al-Dīn 'Abdullah bin Yūsuf. 1960. Naṣob alRāyah Li Ahādīth al-Hidāyah. Al-Qāhirah: Dār Ma’mūn.
Al-Hatāb, Muhammad bin 'Abd al-Rahmman al-Maghribī. 1999. Mawahib al-Jalīl. Bayrūt: Dār Ibn Hazam.

Al-Hașkafī, Muhammad bin 'Alī. 1982. Al-Dar al-Mukhtār. Bayrūt: Dār al-Fikr.

Al-Ḥullī, Abū Qāsim Najm al-Dīn Ja ‘far bin al-Ḥasan. 1985. AlMukhtaṣor al-Nāfi‘ fī Fiqh al-Imāmiyyah. Bayrūt: Dār al-Aḍ̂ā’ .

- Al-Husīn, Aḥmad Farāj. 2002. Nizāām al-Irth wa al-Wașāyā fĩ alFiqh al-Islāmī. Bayrūt: Manshūrāt al-Ḥilbī al-Ḥuqūqiyyah.

- Al-Husnī, 'Abbās bin Ahmad. 1930. Tatimmah al-Rawḍ alNaḍīr. Al-Qāhirah: Maṭba‘ah al-Sa‘ādah.

Al-Albānī, Muḥammad Nașir al-Dīn. 1979. Irwā' al-Ghalīl fī Takhrīj Ahādīth Manār al-Sabīl. Damshiq: al-Maktab al-Islāmī.

Al-Bardīsī, Muḥammad Zakariyyā. 1964. Al-Mirāth wa alWașiyyah fĩ al-Islām. Al-Qāhirah: Dār al-Qawmiyyah Li alTibā‘ah wa al-Nashar.

- Al-Bayhaqī, Aḥmad bin al-Ḥusīn. 1999. Al-Sunan al-Kubrā. Bayrūt: Dār al-Ma‘ārif.

- Al-Buhūtī, al-Shaykh Manșūr. 2000. Kashāf al-Qanā‘ ‘an Matan al-Iqnā‘. Bayrūt: Dār al-Kutub al-'Ilmiyyah.

- $\quad$ Al-Bukhārī, Muḥammad bin Ismā‘īl. 2001. Șoḥịh al-Bukhārī. Bayrūt: Dār Ṭawq al-Najāh.

Al-Dahlawī, Shāh Walī. 2005. Hujjatullah al-Bālighah. Bayrūt: Dār al-Jīl.

Al-Dasūqī, Muhammad bin Aḥmad bin 'Arafah. 2005. Hashiyyah al-Dasūqī 'alā al-Sharḥ al-Kabīr. Bayrūt: Dār al-Fikr.

Al-Dārqutn̄ī, 'Alī bin 'Umar Abū al-Hasan. 2004. Sunan alDārquṭī. Bayrūt: Mu’assasah al-Risālah.

Al-Dāwud, Aḥmad Muḥammad 'Alī. 2009. Al-Ḥuqūq alMuta'alliqah bi al-Tarikah bayna al-Fiqh wa al-Qānūn. 'Ammān: Dār al-Thaqāfah li al-Nashar wa al-Tawzī‘ .

Al-Dhihbī, Muhammad al-Sayyid Husīn. 2000. Al-Tafsīr wa alMufassirūn. Al-Qāhirah: Maktabah Wahbah.

Al-Jașāṣ, Aḥmad bin 'Alī Abū Bakar al-Rāzī. 1985. Aḥām alQur'ān. Bayrūt: Dār Ihyyā’ al-Turāth al-'Arabī.

Al-Jubūrī, 'Abdullah Muhammad. 2008. Ahkām al-Mawārīth wa al-Wașāyā wa al-Waqaf fì al-Shari'ah al-Islāmiyyah. Kuwālā Lumbūr: Fajar Ülūnj.

- Al-Kāsān̄̄, Abū Bakar bin Muhammad. 2005. Badā'i“ al-Ṣonā’i‘ fị Tartīb al-Sharā'i‘'. Al-Qāhirah: Dār al-Hadīth.

- Al-Khirshī, Muhammad bin 'Abdullah. 1997. Hashiyyah alKhirshī. Bayrūt: Dār al-Kutub al-'Ilmiyyah.

Al-Manāwī, 'Abd al-Ra'ūf. 1937. Fayḍ al-Qadīr. Miṣr: alMaktabah al-Tijāriyyah al-Kubrā.

- Al-Mardāwī, 'Alī bin Sulaymān. 1997. Al-Inșāf. Bayrūt: Manshūrāt Muhạmmad 'Alī Bayḍūn.

- Al-Marghīnānī, 'Alī bin Abī Bakar. 2007. Al-Hidāyah fĩ Sharh Bidāyah al-Mubtadī. Bayrūt: Dār Ihyā’ al-Turāth al-'Arabī.

Al-Mubārakafūrī, Muhammad 'Abd al-Rahman bin 'Abd alRahịm. 2001. Tuḥah al-Aḥwadhī Bisharḥ Jāmi` al-Tirmidhī. Bayrūt: Dār al-Kutub al-'Ilmiyyah.

Al-Nasā'̄i, Ahmad bin Shu'īb. 1990. Tafsīr al-Nasā'ī. Bayrūt: Mu'assasah al-Kutub al-Thaqāfiyyah.

- $\quad$ Al-Nasā'ī, Aḥmad bin Shu'īb. 1997. Sunan al-Nasā'ī. Bayrūt: Dār al-Ma'rifah.

- Al-Nawawī, Abū Zakariyyā Mahyȳi al-Dīn Yahyā bin Sharaf. 1972. Al-Minhāj Sharaḥ Șoḥịh Muslim bin al-Hujjāj. Bayrūt: Dār Ihyā' al-Turāth al-'Arabī.

Al-Nawawī, Yahyā bin Sharaf. 2003. Sharạ̣ al-Nawawī 'alā Șohịh Muslim. Bayrūt: Dār al-Kutub al-'Ilmiyyah. 
- Al-Zilmī, Muștofā Ibrāhīm. 2012. Ahkām al-Mīrāth wa alWaṣiyyah wa Ḥ̣aq al-Intiqāl fī al-Fiqh al-Islāmī al-Muqārin wa al-Qānūn. Kurdustān: Markaz Dirāsāt Birlimān.

- Al-Zuhaylī, Muhammad Mustofā. 2001. Al-Farā'id wa alMawārīth wa al-Wașāyā. Damshiq: Dār al-Kalam al-Ṭayyīb.

- Al-Zuhaylī, Wahbah. 1998. Al-Wașāyā wa al-Waqf fĩ al-Fiqh alIslāmī. Bayrūt: Dār al-Fikr.

- Ibnu Hajar al-Haytamī, Ahmad bin Muhammad. 2001. Tuhfah al-Muḥtāj Bisharḥ al-Minhāj. Bayrūt: Dār al-Kutub al-'Ilmiyyah.

- Ibnu Ḥazam, 'Alī bin Aḥmad. 2001. Al-Muḥallā. Bayrūt: Dār Ihyā' al-Turāth al-'Arabī.

- Ibnu al-Muflih, Ibrāhīm bin Muhammad. 1997. Al-Mubdi` fĩ Sharḥ al-Muqni‘ . Bayrūt: Dār al-Kutub al-'Ilmiyyah.

- Ibnu al-Murtaḍā, Ahmad bin Yahyyā. 1975. Al-Bahr al-Zakhkhār. Bayrūt: Mu'assasah al-Risālah.

- Ibnu Daqīq al-'Ayd. 1995. Iḥkām al-Aḥkām Sharḥ 'Umdatul alAḥkām. Bayrūt: Dār al-Jīil. 